\title{
Holocene oxygen isotope record of diatoms from Lake Kotokel (southern Siberia, Russia) and its palaeoclimatic implications
}

\author{
Svetlana S. Kostrova ${ }^{\mathrm{a}}$, Hanno Meyer ${ }^{\mathrm{b}, *}$, Bernhard Chapligin ${ }^{\mathrm{b}}$, Annette $\operatorname{Kossler}^{\mathrm{c}}$, Elena V. Bezrukova ${ }^{\mathrm{a}}$, \\ Pavel E. Tarasov ${ }^{\mathrm{c}}$ \\ a Institute of Geochemistry, Siberian Branch Russian Academy of Sciences, Favorsky Str. 1a, Irkutsk 664033, Russia \\ ${ }^{\mathrm{b}}$ Alfred Wegener Institute for Polar and Marine Research, Research Unit Potsdam, Telegrafenberg A43, 14473 Potsdam, Germany \\ ${ }^{\mathrm{c}}$ Institute of Geological Sciences, Palaeontology, Free University Berlin, Malteserstrasse 74-100, Building D, Berlin 12249, Germany
}

\section{A R T I C L E I N F O}

Article history:

Available online $\mathrm{xxx}$

\begin{abstract}
A B S T R A C T
The oxygen isotope composition of diatom silica $\left(\delta^{18} \mathrm{O}_{\text {diatom }}\right)$ from marine and lake sediments is helpful for the interpretation of the past climate and environments, especially when complemented by other proxy records. This paper presents a Holocene oxygen isotope record of diatoms from Lake Kotokel, located $2 \mathrm{~km}$ east of Lake Baikal in southern Siberia, Russia. The isotope record displays variations in $\delta^{18} \mathrm{O}_{\text {diatom }}$ from +23.7 to $+30.3 \%$ from about $11.5 \mathrm{ka}$ BP until today. Comparing the isotope composition of recent Lake Kotokel water (mean $\delta^{18} \mathrm{O}=-12 \%$ ) to that of the most recent diatom sample $\left(\delta^{18} \mathrm{O}=+27.5 \%\right.$ ), an isotope fractionation in the right order of magnitude was calculated. The Kotokel $\delta^{18} \mathrm{O}$ diatom record is controlled by changes in the isotopic composition of the lake water rather than by lake temperature. Lake Kotokel is a dynamic system triggered by differential environmental changes closely linked with various lake-internal hydrological factors. A continuous depletion in $\delta^{18} \mathrm{O}$ of $6.6 \%$ is observed from early to late Holocene, which is in line with other hemispheric environmental changes (i.e. a mid- to late Holocene cooling). Enhanced evaporation effects and higher relative supply from a southeasterly moisture source explain the relatively heavy isotopic composition in a rather cold early Holocene. In summary, changes in the Holocene $\delta^{18} \mathrm{O}$ diatom record of Lake Kotokel reflect variations in $\delta^{18} \mathrm{O}$ of precipitation linked with both air temperatures $\left(T_{\text {air }}\right)$ as well as evaporation effects and, to a lesser degree, meltwater pulses from the mountainous hinterland and changing atmospheric moisture sources. (c) 2012 Elsevier Ltd and INQUA. All rights reserved.
\end{abstract}

\section{Introduction}

Lacustrine sediments have a great potential to provide high resolution and continuous terrestrial records of environmental change (Antipin et al., 2001; Hövsgöl Drilling Project Group, 2007; Brauer et al., 2008; Nakagawa et al., 2012). This is especially true for lakes that did not dry out during glacial periods or which have never been glaciated and existed for a long time as isolated systems (Bezrukova et al., 2008; Jones and Roberts, 2008; Swann et al., 2010; Wang et al., 2010). During the past decades multi-proxy studies of sediment cores from lakes greatly contributed to the reconstruction of late Quaternary climate and environment and

\footnotetext{
* Corresponding author.

E-mail addresses: kostrova@igc.irk.ru (S.S. Kostrova), hanno.meyer@awi.de (H. Meyer), bernhard.chapligin@awi.de (B. Chapligin), kossler@zedat.fu-berlin.de (A. Kossler), bezrukova@igc.irk.ru (E.V. Bezrukova), ptarasov@zedat.fu-berlin.de (P.E. Tarasov).
}

allowed correlation with continuous archives stored in marine sediments and ice cores (Jones and Roberts, 2008; Svensson et al., 2008; Mügler et al., 2010).

The use of oxygen isotopes recorded from biogenic or sedimentary hosts within lake sediments has become an increasingly common technique (Leng and Marshall, 2004; Jones and Roberts, 2008). A large number of such records from different parts of the world (Leng and Marshall, 2004; Leng and Barker, 2006; Swann and Leng, 2009), including the Lake Baikal region (Morley et al., 2005; Kalmychkov et al., 2007; Mackay et al., 2008, 2011), have been published and demonstrate the potential for reconstructing past climate changes from the oxygen isotope composition of biogenic silica $\left(\delta^{18} \mathrm{O}_{\mathrm{Si}}\right)$ in both quantitative and qualitative ways.

The oxygen isotope composition of diatom frustules $\left(\delta^{18} \mathrm{O}_{\text {diatom }}\right)$ extracted from lacustrine sediments is an important tool to quantitatively estimate changes in temperature, precipitation patterns, or evaporation in terrestrial ecosystems (Jones et al., 2004; Leng and Marshall, 2004; Leng and Barker, 2006). Diatoms are photosynthetic algae with cell walls of silica characterized by two 
intricately-patterned valves allowing most fossil taxa to be identified at the species level. Characteristic valve morphology of different diatom taxa and their growth in almost all aquatic environments make the analysis of fossil diatoms in lake sediments a particularly useful method for reconstructing spatial and temporal ecological, environmental and climate changes at the local to regional scale (Battarbee et al., 2001; Paul et al., 2010; Kossler et al., 2011). The change in the $\delta^{18} \mathrm{O}_{\text {diatom }}$ may reflect changing water temperature $\left(T_{\mathrm{w}}\right)$ (Shemesh et al., 1992; Brandriss et al., 1998; Dodd and Sharp, 2010) and the oxygen isotope composition of the water $\left(\delta^{18} \mathrm{O}_{\mathrm{w}}\right)$ in which biogenic silica formed (Labeyrie, 1974; Shemesh et al., 1992). The $\delta^{18} \mathrm{O}_{\mathrm{w}}$ values depend on the oxygen isotope composition of atmospheric precipitation $\left(\delta^{18} \mathrm{O}_{\mathrm{p}}\right)$ and the hydrological background of the lake (e.g. inflow and outflow, evaporation, lake level change; Leng and Barker, 2006). As variations in $\delta^{18} \mathrm{O}_{\mathrm{p}}$ depend largely on changes in air temperature (Dansgaard, 1964), under certain conditions (e.g. short residence times) the isotope composition of lake water may be a direct indicator of atmospheric precipitation and air temperature, and in these cases $\delta^{18} \mathrm{O}_{\text {diatom }}$ can be correlated to regional climate.

If fully understood, diatom isotope records have the potential to provide a regional picture of hydrological and climatic change. However, because there are multiple controls over the isotope composition of lake waters, the interpretation of these records requires a careful analysis of all potential influences (Jones and Roberts, 2008).

This study deals with Lake Kotokel $\left(52^{\circ} 50^{\prime} \mathrm{N}, 108^{\circ} 10^{\prime} \mathrm{E}\right)$ located $2 \mathrm{~km}$ east of Lake Baikal (Fig. 1a). The lake is up to $14 \mathrm{~m}$ deep, and is characterized by a relatively small catchment area of $183 \mathrm{~km}^{2}$ (Kuz'mich, 1988) and by a short water residence time of about 7 years (Shichi et al., 2009). Bottom sediments of Lake Kotokel have been shown to be an excellent archive of vegetation and environmental dynamics in southern Siberia over the last 50 ka (Shichi et al., 2009; Bezrukova et al., 2010). Although high potential of the Kotokel sediment for palaeoenvironmental and palaeoecological studies was recognized already in the 1960s and 1970s (Korde, 1968; Vipper and Smirnov, 1979), only recently new highresolution and more accurately AMS-dated palaeoenviromental records are available for multi-proxy studies. Shichi et al. (2009) demonstrated that Lateglacial-Holocene sediment samples from Lake Kotokel are rich in biogenic silica (BSi) reaching up to $27 \%$. BSi is mainly preserved in diatoms, which are particularly abundant in the Holocene sediments (Bezrukova et al., 2010).

Using the findings of these latter studies, the $\delta^{18} \mathrm{O}$ analysis of diatoms from Lake Kotokel contributes to a better understanding of the late Quaternary environments and climate history of the region, and to complement the longer records obtained from Lake Baikal deep-water sediments, which suffer from several problems influencing accurate dating and environmental reconstructions. These include the hard-water effect and low organic content (Colman et al., 1996), partial dissolution of diatoms (Battarbee et al., 2005) and pollen grains (Demske et al., 2005), long residence time and, thus, lower sensitivity to abrupt climate changes (Prokopenko et al., 2007; Watanabe et al., 2009). Additionally, $\delta^{18} \mathrm{O}$ records from small lakes in this region of Asia are sparse. Both the geographical location of Lake Kotokel in the southern taiga with nearby steppe vegetation and the lake hydrology suggest that its $\delta^{18} \mathrm{O}_{\text {diatom }}$ record should be sensitive to changes in the regional climate. In order to test this hypothesis, the main aim of the present study was to perform the $\delta^{18} \mathrm{O}$ analysis of diatoms from Lake Kotokel for the upper $500-\mathrm{cm}$ of the KTK2 core spanning the whole Holocene interval in order to test the suitability of the record for reconstructing climatic variability in the Baikal region. The aim is to establish $\delta^{18} \mathrm{O}$ of diatom silica as an independent climate proxy complementing environmental interpretations based on the existing pollen and diatom records.

\section{Study area}

Lake Kotokel has an area of $\sim 69 \mathrm{~km}^{2}$, is $\sim 15 \mathrm{~km}$ long and $\sim 6 \mathrm{~km}$ wide (Bochkarev and Karnaukhov, 1936; Galaziy, 1993). The average water depth is $5-6 \mathrm{~m}$. The average lake water temperature from May to October is about $18^{\circ} \mathrm{C}$. The modern measured lake water $\mathrm{pH}$ varies between 6.8 and 7.3 (Kuz'mich, 1988). In the west a lowelevated mountain ridge (500-729 $\mathrm{m}$ a.s.l.) separates Lake Kotokel (458 $\mathrm{m}$ a.s.l.) from Lake Baikal (455 $\mathrm{m}$ a.s.l.), and the Ulan-Burgasy Ridge (up to $2033 \mathrm{~m}$ a.s.l.) is located east of Kotokel. The lake has an outflow to Lake Baikal (Fig. 1) via the rivers Istok, Kotochik and Turka (Bochkarev and Karnaukhov, 1936; Kozhov, 1950). However, there is no evidence that the Lake Baikal water (and diatoms) have penetrated to Lake Kotokel during the last 50 ka (Shichi et al., 2009; Bezrukova et al., 2010). Kozhov (1939) indicated the existence of

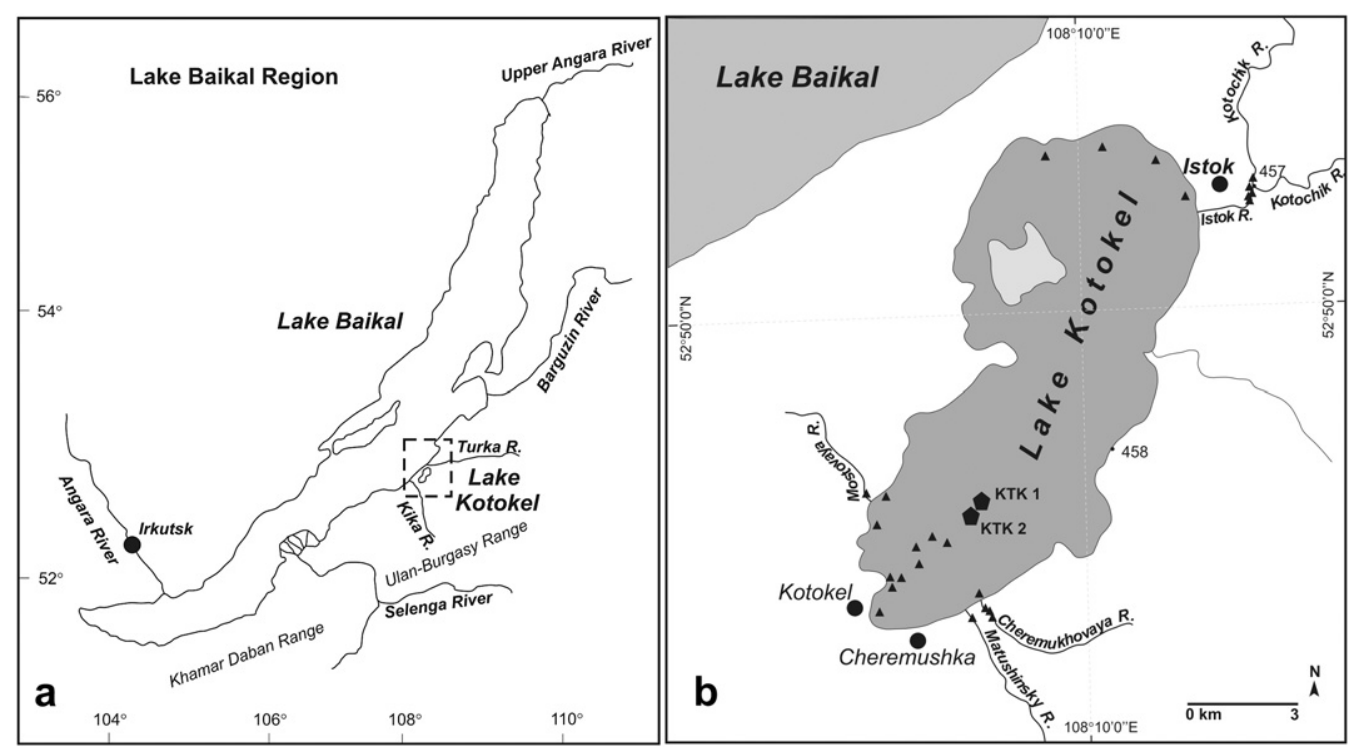

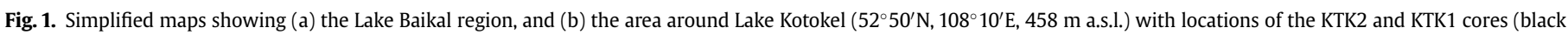
pentagon) and water sampling sites (black triangles) used in this study. 
a marked 10-15 m high ancient terrace at Lake Kotokel. However, the age of this terrace is unknown.

The region is characterized by continental climate with cold winters and moderately warm summers. The lake ice-cover generally stays for about six months from the end of October to early-May (Bochkarev and Karnaukhov, 1936; Egorov, 1950). Around the lake the average air temperature is approximately $-20{ }^{\circ} \mathrm{C}$ in January and $+16^{\circ} \mathrm{C}$ in July, and the mean annual values of precipitation and temperature are approximately $400 \mathrm{~mm}$ and $-2{ }^{\circ} \mathrm{C}$ respectively (Alpat'ev et al., 1976; Galaziy, 1993). A western air-mass drift is predominant throughout the year (Numaguti, 1999; Kurita et al., 2004) though weakened in July and August, when south-eastern cyclonic activity increases along the Mongolian front, bringing to the region warm and wet air and often causing heavy rainfalls (Ladeischikov, 1977; Lydolph, 1977; Gustokashina, 2003; Bezrukova et al., 2008). Precipitation is generally low during late autumn and winter, when cold and sunny weather associated with the highpressure cell centred over eastern Siberia and Mongolia predominates in the region (Alpat'ev et al., 1976).

\section{Materials and methods}

\subsection{Core lithology and age determination}

The longest sediment core KTK2 (Figs. 1b and 2) from Lake Kotokel to date was retrieved using a Livingston-type piston corer from a depth of $\sim 3.5 \mathrm{~m}$ in the southern part of the lake in August 2005 and subsequently studied for pollen and diatoms (see Shichi et al., 2009; Bezrukova et al., 2010 for details). The latter study reported that a reservoir effect is not an issue in Lake Kotokel and demonstrated that the upper $506 \mathrm{~cm}$ of the KTK2 core, consisting of soft brownish-black gyttja (Fig. 2a), was deposited during the last $\sim 11,650$ years (calendar ages are used consistently in this study), i.e. covers the whole Holocene interglacial. The age-depth relationship of the analysed Holocene part of the KTK2 core (Bezrukova et al., 2010) was established on the basis of AMS radiocarbon dates (Fig. 2b). The Holocene onset is also supported by the results of pollen and diatom analyses.

\subsection{Diatom record}

In the $1253 \mathrm{~cm}$ long KTK2 core diatoms were analysed from a total of 125 samples, taken at 10-cm intervals (see Bezrukova et al., 2010 for details of the extraction method and analysis). Generally high diatom concentrations (up to $136.5 \times 10^{6}$ valves $\mathrm{g}^{-1}$ ) allowed easy counting of at least 300-600 diatom valves per sample in all analysed Holocene samples. The upper $500 \mathrm{~cm}$ of the record show continuous dominance of a relatively heavy diatom with thick siliceous frustules, Aulacoseira granulata (45-98\%) common in water reservoirs with a relatively high nutrient content, requiring high water turbulence to maintain its position in the water column (Gómez et al., 1995). Staurosira construens is another dominant taxon at some levels with abundances between 2 and 40\% (Fig. 2c). Ellerbeckia arenaria f. teres as well as Pseudostaurosira brevistriata, Ophephora martyi and Staurosirella pinnata agg. are present at low abundances (Fig. 2c). The diatom assemblages of the uppermost $130 \mathrm{~cm}$ of the KTK2 record (accumulated since $\sim 4$ ka BP) show only slight differences from the early and middle Holocene assemblages, i.e. a slight decrease in $A$. granulata, the increase in abundances of $E$. arenaria f. teres (up to $11 \%$ ), and the total disappearance of $S$. pinnata agg. (Fig. 2c).

\subsection{Sample cleaning}

For the oxygen isotope analyses, 87 samples were taken from the upper part of the core (interval $500-0 \mathrm{~cm}$ ) separated in $2 \mathrm{~cm}$ slices, yielding an average temporal resolution of about 130 years throughout the past $\sim 11.5 \mathrm{ka}$. Separation and cleaning of diatom valves extracted from the sediment matrix was carried out using a multi-stage technique first applied by Kalmychkov et al. (2005) at the Institute of Geochemistry (Irkutsk), as described here.

Stage 1 aims to remove organic matter and clay particles. Sediment samples were heated to $50{ }^{\circ} \mathrm{C}$ in $30 \% \mathrm{H}_{2} \mathrm{O}_{2}$ for $6 \mathrm{~h}$ (or until chemical reaction ends) for removal of organic matter. The samples were then sieved to remove the clay fraction using a $5 \mu \mathrm{m}$ sieve. In order to remove persistent organic matter a $1: 1$ mixture of concentrated nitric (70\%) and perchloric (72\%) acids $\left(\mathrm{HNO}_{3}: \mathrm{HClO}_{4}\right)$

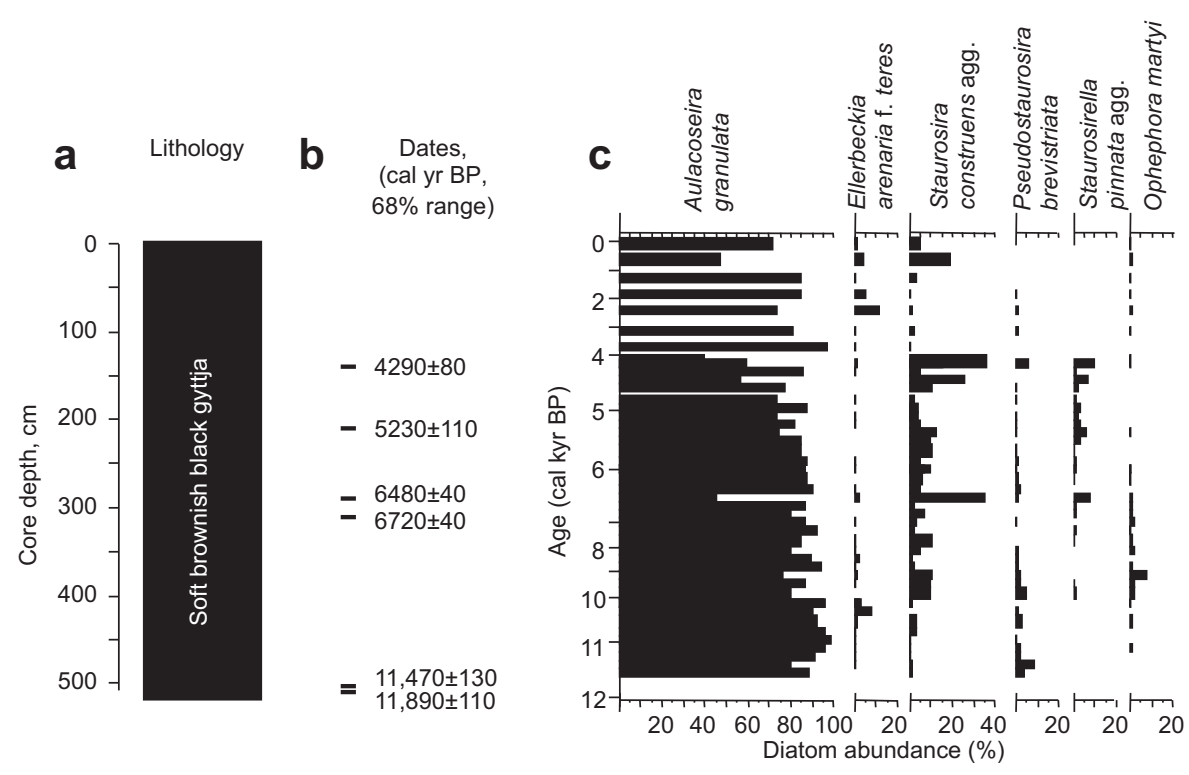

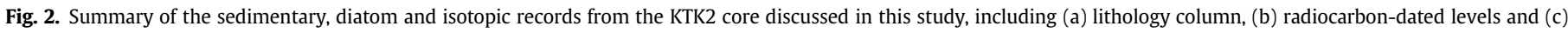
simplified diatom diagram (modified after Bezrukova et al., 2010). 
at $50{ }^{\circ} \mathrm{C}$ was used. Subsequently, the samples were washed and dried at $50{ }^{\circ} \mathrm{C}$.

Stage 2 applies 'trimethylsilylation reaction' (Kashutina et al., 1975 ) to make the surface of diatoms hydrophobic and to facilitate their extraction. As a result of this reaction the substitution of the protons of silanol groups $(\equiv \mathrm{Si}-\mathrm{OH})$ by non-polar radicals occurs, and the diatom frustules become hydrophobic. Whilst the other sediment particles are sinking in water, diatoms remain at the surface and can be collected from the water surface. The reaction is described by the following Equation (1) (Kashutina et al., 1975):

$\equiv \mathrm{Si}-\mathrm{OH}+\left(\mathrm{CH}_{3}\right)_{3} \mathrm{Si}-\mathrm{Cl} \rightarrow \equiv \mathrm{Si}-\mathrm{O}-\mathrm{Si}\left(\mathrm{CH}_{3}\right)_{3}+\mathrm{HCl}$

The samples were placed into a $50 \mathrm{ml}$ flask, filled with solvent (chloroform $\mathrm{CHCl}_{3}$ ) and $5 \mathrm{ml}$ silylation reagent (trimethylchlorsilan $\left.\left(\mathrm{CH}_{3}\right)_{3} \mathrm{SiCl}\right)$. After the reaction was completed (in about $24 \mathrm{~h}$ ), the samples were separated from the solvent through paper filter, washed with chloroform, and dried at room temperature.

Stage 3 is used to separate diatoms from the terrigenous fraction. The samples were first placed in separating funnels. After shaking with water the terrigenous fraction sank to the bottom of the separating funnel, whilst the diatom frustules were collected from the water surface. The silyl groups $\left(-\mathrm{Si}\left(\mathrm{CH}_{3}\right)_{3}\right)$ were then removed from the surface by hydrochloric acid (Equation (2)):

$\equiv \mathrm{Si}-\mathrm{O}-\mathrm{Si}\left(\mathrm{CH}_{3}\right)_{3}+\mathrm{HCl} \leftrightarrow \equiv \mathrm{Si}-\mathrm{OH}+\left(\mathrm{CH}_{3}\right)_{3} \mathrm{SiCl}$

For this operation clean samples were dried. After that $100 \mathrm{ml}$ of concentrated (38\%) hydrochloric acid $(\mathrm{HCl})$ were added to each sample. The reaction was carried out at $60^{\circ} \mathrm{C}$ for a rapid removal of trimethylchlorsilan and hexamethyldisiloxane produced during trimethylchlorsilan hydrolysis. The reaction was continued until all diatoms settled to the bottom of the glass. The collected diatoms were carefully washed and dried at $50{ }^{\circ} \mathrm{C}$, the degree of purity assessed (cf. Section 3.4) and if further cleaning was required an additional heavy liquid separation (HLS) was performed (cf. Section 3.5).

\subsection{Contamination assessment}

The degree of purification was determined using the method of Chapligin et al. (2012): after having completed the cleaning procedure, the purity of the samples was estimated using Scanning Electron Microscope (SEM)-energy-dispersive X-ray microanalysis (EDXA). SEM and microanalyses were done with a ZEISS ULTRA 55 Plus Schottky-type field emission scanning electron microscope (FESEM) at the German Research Centre for Geoscience (GFZ), Potsdam. The FESEM is equipped with an energy-dispersive system and a silicon-drift detector (UltraDry SDD) provided by Thermo Fisher Scientific. Further SEM images were taken with a Zeiss Supra 40 VP SEM at the Institute of Geological Sciences of the Free University Berlin.

For SEM analyses, samples with less than $1 \mathrm{mg}$ of purified diatom material were diluted with distilled water, mixed and one drop was then pipetted on conductive-tabs mounted on aluminium stubs and then dried. For EDXA dry samples were placed on stubs. In both cases, dry stub samples were then carbon coated.

Due to the presence of larger-sized diatom frustules the suggested excited beam area of $200-250 \mu \mathrm{m}$ in diameter for the $>10 \mu \mathrm{m}$ fraction (Chapligin et al., 2012) was increased to $300-500 \mu \mathrm{m}$ for a better reproducibility. The quantitative analysis was performed using the standardless procedure; the results were expressed as weight percentages (displayed as oxides).
As $\mathrm{Al}_{2} \mathrm{O}_{3}$ is less sensitive to small variations in the chemical composition of (clay) minerals the percentage of contamination $\left(c_{\text {cont }}, \%\right)$ was calculated according to the Equation (3) (Brewer et al., 2008):

$c_{\text {cont }}[\%]=c\left(\mathrm{Al}_{2} \mathrm{O}_{3}\right)_{\text {sample }} / c\left(\mathrm{Al}_{2} \mathrm{O}_{3}\right)_{\text {cont }} \cdot 100$

where $c\left(\mathrm{Al}_{2} \mathrm{O}_{3}\right)_{\text {sample }}$ is the measured $\mathrm{Al}_{2} \mathrm{O}_{3}$ percentage analysed by EDXA for an individual sample and $c\left(\mathrm{Al}_{2} \mathrm{O}_{3}\right)_{\text {cont }}$ is the average $\mathrm{Al}_{2} \mathrm{O}_{3}$ percentage of the contamination.

The isotopic effects of the terrigenous contamination were removed using the Equation (4) following Swann and Leng (2009):

$\delta^{18} \mathrm{O}_{\text {corr }}=\left(\delta^{18} \mathrm{O}_{\text {measured }}-\delta^{18} \mathrm{O}_{\text {cont }} \cdot c_{\text {cont }} / 100\right) /\left(c_{\text {diatom }} / 100\right)$

where $\delta^{18} \mathrm{O}_{\text {measured }}$ is the original measured value, $\delta^{18} \mathrm{O}_{\text {cont }}$ represents the average $\delta^{18} \mathrm{O}$ of the analysed terrigenous sample, $c_{\text {cont }}$ is the percentage of contamination identified from the above equation and $c_{\text {diatom }}$ is percentage of diatom material calculated as $\left(100 \%-c_{\text {cont }}\right)$, respectively, within the analysed sample.

The average $\delta^{18} \mathrm{O}$ of terrigenous material/mineral matter was determined by analysing the heavy fraction after having applied HLS. The heavy fractions from all core samples where HLS was used were merged into three samples $(0-130 \mathrm{~cm}, 150-260 \mathrm{~cm}$, 420-500 cm) to gain enough material for both EDXA and isotope analyses. The average from all three analyses defined the average isotope and element composition from contamination.

\subsection{The grade of purification of diatoms and contamination correction}

The oxygen isotope analysis of diatom silica requires highly pure samples because even a small proportion of contamination can significantly influence the oxygen isotope composition (Morley et al., 2004; Lamb et al., 2005; Brewer et al., 2008; Mackay et al., 2011). After the cleaning procedure eight samples were considered as unsuitable for isotopic analysis due to too small remaining weight or too high contamination (EDXA: $<90 \% \mathrm{SiO}_{2}$, $\sim 5.5 \%$ of $\mathrm{Al}_{2} \mathrm{O}_{3}$ ). Among the 87 samples, 46 ranged between 98.0 and $99.7 \% \mathrm{SiO}_{2}$, and between $0.1 \%$ (detection limit) and $0.86 \%$ $\mathrm{Al}_{2} \mathrm{O}_{3}$. These 46 samples were analysed for oxygen isotopes without additional cleaning. Further 33 samples contained $\mathrm{SiO}_{2}$ percentages ranging between 93.0 and $97.9 \%$, and up to $2.8 \%$ $\mathrm{Al}_{2} \mathrm{O}_{3}$. These samples were additionally cleaned using HLS. Samples were mixed with a sodium polytungstate solution (SPT; $3 \mathrm{Na}_{2} \mathrm{WO}_{4} 9 \mathrm{WO}_{3} \cdot \mathrm{H}_{2} \mathrm{O}$ ), with a density of $2.2 \mathrm{~g} / \mathrm{cm}^{3}$, and then centrifuged at $2500 \mathrm{rpm}$ for $30 \mathrm{~min}$. The SPT was removed by repeated centrifuge washing with ultrapure water. After HLS the $\mathrm{Al}_{2} \mathrm{O}_{3}$ percentages decreased to $0.2-1.0 \%$ while the $\mathrm{SiO}_{2}$ percentages increased to $97.5-99.2 \%$ depending on the initial element composition of the sample before HLS. HLS allowed separating the terrigenous fraction from diatom frustules (Fig. 3a). The heavy fraction acted as a reference for determining the element composition and the $\delta^{18} \mathrm{O}$ values of the "contamination" in general. All samples with no obvious impurities according to SEM and EDXA (Figs. 3 and 4b) were analysed for oxygen isotopes.

The average $\delta^{18} \mathrm{O}_{\text {cont }}$ value from the three terrigenous samples merged from the remaining heavy fraction after HLS was $+8.1 \pm 0.1 \%$ o The average percentage of $\mathrm{Al}_{2} \mathrm{O}_{3}$ analysed by EDXA was $13.9 \pm 0.9 \%$. Both values were taken for correcting the measured isotopic 


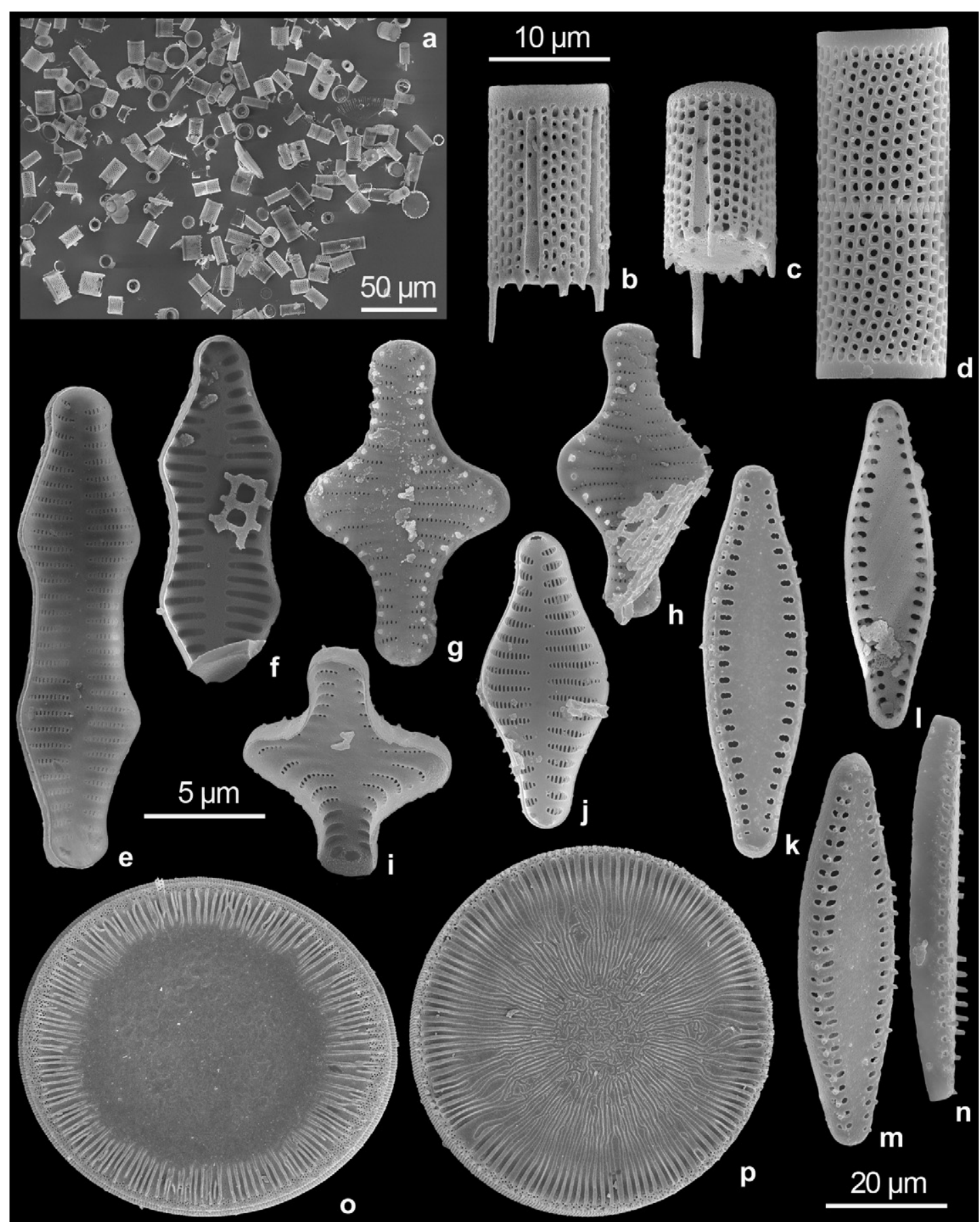

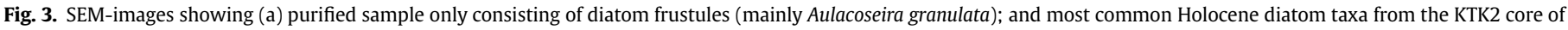

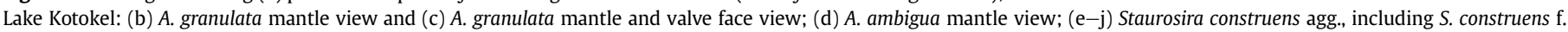

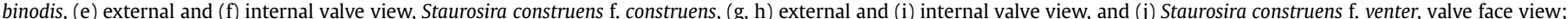

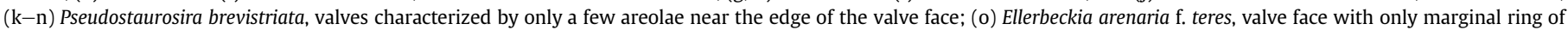

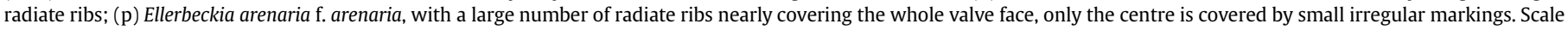
bar is equal to (a) $50 \mu \mathrm{m}$; (b-d) $10 \mu \mathrm{m}$; (e-n) $5 \mu \mathrm{m}$ and (o-p) $20 \mu \mathrm{m}$.

composition (Equations (3) and (4)). 14 samples with $<1.2 \%$ contamination had a difference between $\delta^{18} \mathrm{O}_{\text {corr }}$ and $\delta^{18} \mathrm{O}_{\text {measured }}$ below the instrument's error ( $\mathrm{SD}= \pm 0.25 \%$ ). 18 samples had $\mathrm{Al}_{2} \mathrm{O}_{3}$ concentrations $>0.6 \%$ resulting in $c_{\text {cont }}>4.5 \%$ with corrections in $\delta^{18} \mathrm{O}>0.9 \%$. The $\delta^{18} \mathrm{O}_{\text {corr }}$ values are displayed in Fig. $4 \mathrm{a}$ (black bold line) together with the original measurements (grey line). The contamination correction did not cause any significant changes of the overall trend (Fig. 4a, b).

\subsection{Oxygen isotope analysis of biogenic silica}

Biogenic silica contains loosely-bound oxygen (i.e. $\mathrm{H}_{2} \mathrm{O}, \mathrm{OH}-$ groups) reaching up to $7-12 \%$ by weight (Haimson and Knauth, 1983; Matheney and Knauth, 1989; Lücke et al., 2005) that needs to be removed prior to isotope analysis. Before $\delta^{18} \mathrm{O}$ analysis of diatoms, the hydrous layer was removed using the inert Gas Flow Dehydration (iGFD) method (Chapligin et al., 2010). Then, laser 


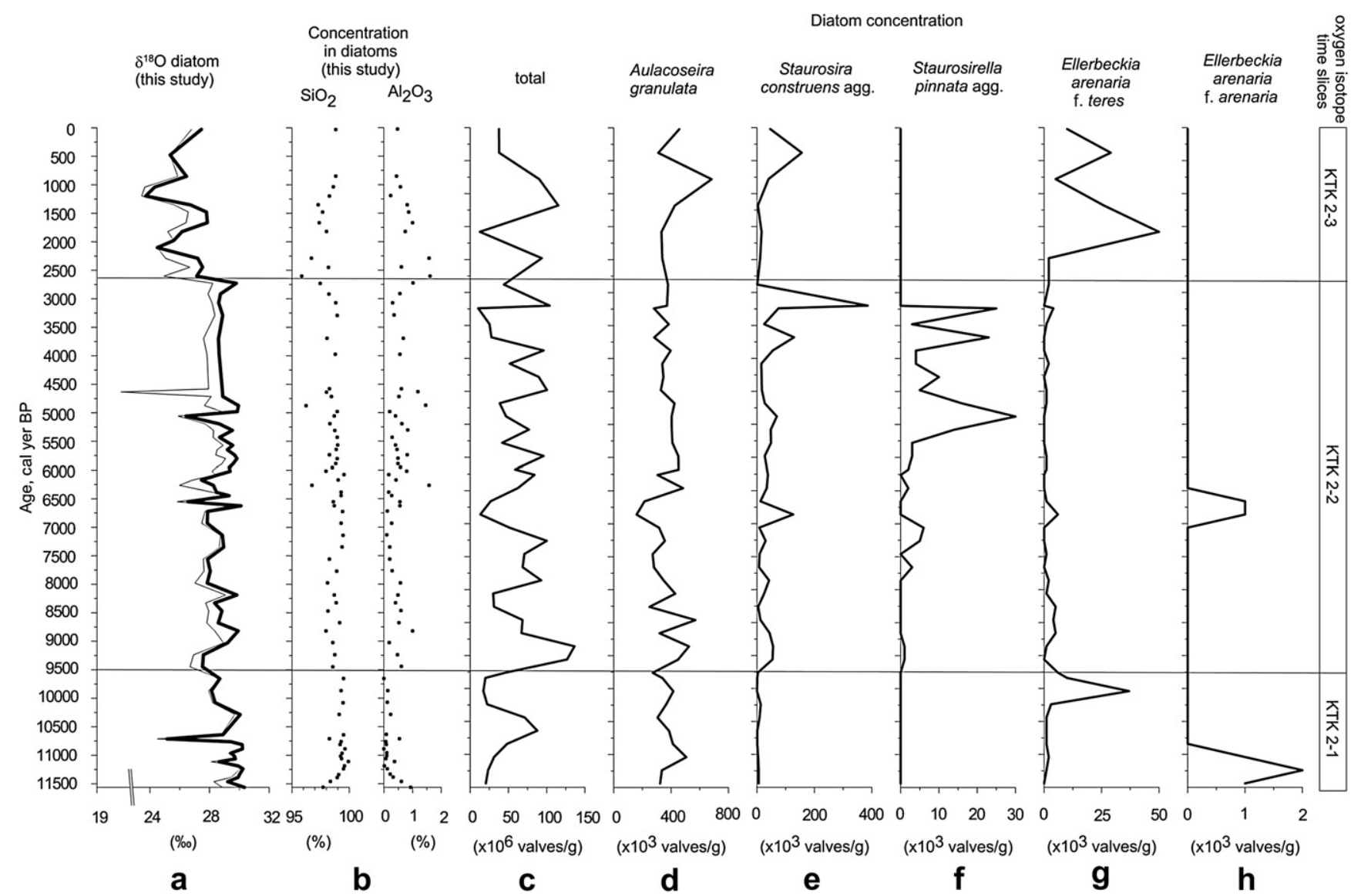

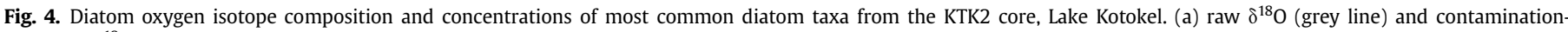

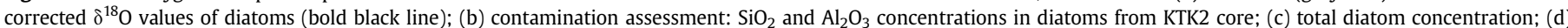

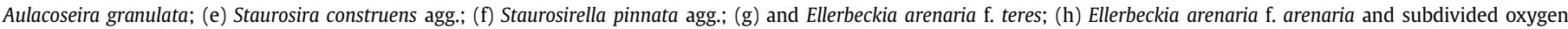
isotope zones. Note: Diatom species concentrations are given at different scales.

fluorination under $\mathrm{BrF}_{5}$ atmosphere was used for the liberation of $\mathrm{O}_{2}$ (Equation (5); Clayton and Mayeda, 1963) from about 1 to $1.5 \mathrm{mg}$ of pure diatom material:

$\mathrm{SiO}_{2}+2 \mathrm{BrF}_{5} \rightarrow \mathrm{O}_{2}+\mathrm{SiF}_{4}+2 \mathrm{BrF}_{3}$

The liberated $\mathrm{O}_{2}$ of the diatom sample is separated of byproducts in cold traps and directed to a molecular sieve. From the molecular sieve the sample enters a PDZ Europa 2020 mass spectrometer (MS-2020; now supplied by Sercon Ltd., UK) for oxygen isotope analysis at the Isotope laboratory of the Alfred Wegener Institute for Polar and Marine Research (Potsdam). The final $\delta^{18} \mathrm{O}$ value of the diatom sample is calculated relative to Vienna Standard Mean Ocean Water (V-SMOW) according to:

$$
\left.\delta^{18} \mathrm{O}_{\text {sample }}=\left(\left({ }^{18} \mathrm{O} /{ }^{16} \mathrm{O}\right)_{\text {sample }} /\left({ }^{18} \mathrm{O} /{ }^{16} \mathrm{O}\right)_{\mathrm{ref}}\right)-1\right) \cdot 1000
$$$$
\% \text { VSMOW }
$$

Long-term standard measurements of $\delta^{18} \mathrm{O}$ in silica display standard deviations of $1 \sigma \leq \pm 0.15 \%$ for quartz as well as of $1 \sigma \leq \pm 0.25 \%$ for biogenic silica (Chapligin et al., 2010). In general, every fifth sample is a biogenic standard used to verify the quality of the analyses. For the Lake Kotokel series the working standard BFC (a diatomite from Shasta County California) was used $\left(\delta^{18} \mathrm{O}=+28.80 \pm 0.18 \%, 1 \sigma, n=24\right)$ matching the results from the inter-laboratory comparison $\left(\delta^{18} \mathrm{O}=+29.0 \pm 0.3 \%, n=7\right.$ laboratories; see Chapligin et al., 2011).

\subsection{Water sampling and stable water isotope analysis}

Surface water from Lake Kotokel and other Baikal region lakes, rivers and streams were sampled during July 2011. The water was collected in the southern part of Lake Kotokel, next to the KTK2 coring site, and in the northern part, where the lake has a connection to Lake Baikal (i.e. the rivers Istok/Kotochik, see Fig. 1 for sampling site locations). Atmospheric precipitation samples were collected from May to September 2011 in Irkutsk, about $270 \mathrm{~km}$ west of Lake Kotokel. Water and air temperatures were also recorded. After sampling, all samples were stored cool in airtight bottles prior to isotope analyses.

Hydrogen and oxygen isotope composition of 41 samples was measured with a Finnigan MAT Delta-S mass spectrometer at the AWI in Potsdam using equilibration techniques. They are given as per mil difference to $\mathrm{V}$-SMOW, with internal $1 \sigma$ errors of better than $\pm 0.8 \%$ and $\pm 0.1 \%$ for $\delta \mathrm{D}$ and $\delta^{18} \mathrm{O}$, respectively (Meyer et al., 2000).

\section{Results}

\subsection{Isotope composition of lake water and atmospheric precipitation}

The results of stable water isotope analyses are presented in $\delta^{18} \mathrm{O}-\delta \mathrm{D}$ diagrams (Fig. 5) with respect to the Global Meteoric Water Line (GMWL; $\delta \mathrm{D}=8 \cdot \delta^{18} \mathrm{O}+10$ ), in which fresh surface waters (Craig, 1961) and precipitation (Rozanski et al., 1993) are 


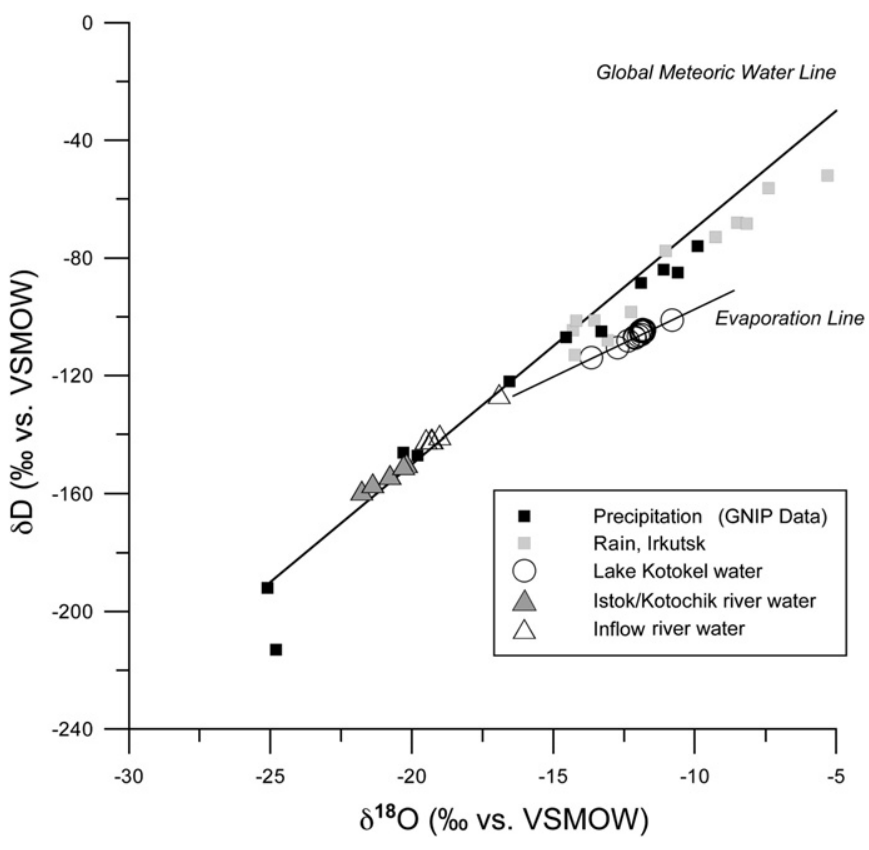

Fig. 5. $\delta^{18} \mathrm{O}-\delta \mathrm{D}$ diagram for Lake Kotokel and rain water (sampled in Irkutsk) as well as river water samples connected to the lake collected between July and September, 2011 (compare Table 1). Additionally, GNIP data for Irkutsk precipitation, the Global Meteoric Water Line as well as an evaporation line for Lake Kotokel water are given.

correlated on a global scale. Dansgaard (1964) determined a global linear relationship between mean annual air temperature and oxygen isotope composition to be $\delta^{18} \mathrm{O}=0.695 \cdot T-13.6 \%$ SMOW. Thus, in general, the lowest $\delta^{18} \mathrm{O}$ and $\delta \mathrm{D}$ values (or lightest isotopic composition) roughly reflect the coldest temperatures. Slope and intercept in the $\delta^{18} \mathrm{O}-\delta \mathrm{D}$ diagram are valuable indicators for the identification of (1) precipitation deriving from the evaporation of open water bodies and (2) participation of secondary evaporation processes. The deuterium excess $\left(d=\delta \mathrm{D}-8 \cdot \delta^{18} \mathrm{O}\right)$ introduced by Dansgaard (1964) is an indicator for kinetic (non-equilibrium) fractionation processes and generally related to conditions (i.e. humidity, sea surface temperature, wind speed) in the initial moisture source region (Merlivat and Jouzel, 1979; Meyer et al., 2002, 2010).

In Table 1 , hydrogen and oxygen isotope minimum, mean, and maximum values, standard deviations, slopes and intercepts in the $\delta^{18} \mathrm{O}-\delta \mathrm{D}$ diagram (Fig. 5) are given for the Lake Kotokel water. For comparison, stable isotopic compositions of rain water and water of the rivers connected to Lake Kotokel are presented. The isotopic composition of lake water in July 2011 ranges between $-10.8 \%$ and $-13.7 \%$ for $\delta^{18} \mathrm{O}$ and from $-101.2 \%$ to $-113.9 \%$ for $\delta \mathrm{D}$
(Table 1 ). The $d$ excess varies from $-4.7 \%$ to $-14.8 \%$ with a mean value of $-10.0 \%$.

\subsection{Oxygen isotope record of diatoms}

The $\delta^{18} \mathrm{O}_{\text {corr }}$ values of the investigated part $(0-500 \mathrm{~cm}$ depth) within core KTK2 vary between +23.7 and $+30.3 \%$ (Fig. $4 a$ ). In general, through the core a gradual depletion of $6.6 \%$ in $\delta^{18} \mathrm{O}$ is observed in diatom frustules from the bottom of the core towards the sediment surface. The linear correlation between $\delta^{18} \mathrm{O}_{\text {diatom }}$ and calibrated ages (in yr) yields: $\delta^{18} \mathrm{O}_{\text {diatom }}=0.0003$ age $(y)+25.79$ $\left(r^{2}=0.43\right)$.

Maximum $\delta^{18} \mathrm{O}$ values $(+29.2$ to $+30.3 \%$ ) are registered during the beginning of the Holocene ( 11.5-11.2 ka BP). After a sharp drop to $+25.2 \%$ at $\sim 10.7 \mathrm{ka}$, and subsequent rise to $+30.1 \%$ o $\delta^{18} \mathrm{O}$ values gradually decrease to $+27.5 \%$ from $\sim 10.3$ to $9.4 \mathrm{ka}$ BP. The interval between $\sim 11.5$ and 9.4 ka BP with relatively high $\delta^{18} \mathrm{O}$ values is considered as oxygen isotope zone KTK2-1.

The interval $\sim 9.4-2.7 \mathrm{ka}$ BP (oxygen isotope zone KTK2-2) displays intermediate and relatively constant $\delta^{18} \mathrm{O}$ values ranging between +27.5 and $+29.9 \%$ gradually increasing with time. However, there are a number of peaks in this interval with sharp variations in $\delta^{18} \mathrm{O}$ between about $+30-29 \%$ and about $+27-26 \%$. Smaller maxima in this interval are observed at $\sim 8.7, \sim 8.2, \sim 6.7$, $\sim 5.8$, $\sim 4.9$, and $\sim 2.7 \mathrm{ka} \mathrm{BP}$, whereas smaller minima occur at $\sim 9.3,6.6$ and $5.1 \mathrm{ka}$ BP. A minimum $\delta^{18} \mathrm{O}$ value of $+20.4 \%$ has been registered at $\sim 4.6 \mathrm{ka} \mathrm{BP}$, which could be measured only once due to a lack of material. Therefore, this unverified $\delta^{18} \mathrm{O}$ value was left out from further interpretation (Fig. 4a).

The youngest interval $(\sim 2.7-0 \mathrm{ka} \mathrm{BP}$; oxygen isotope zone KTK2-3) is characterized by relatively low $\delta^{18} \mathrm{O}$ values ranging from +23.7 to $+29.8 \%$. Between $\sim 2.7$ and $2.1 \mathrm{ka} \mathrm{BP}$ there is a sharp decrease in $\delta^{18} \mathrm{O}$ values from +29.8 to $+24.5 \%$ with subsequent increase to $+27.9 \%$ at $\sim 1.6 \mathrm{ka}$ BP. A sharp decline of $\delta^{18} \mathrm{O}$ values from +27.8 to $+23.7 \%$ is observed at $\sim 1.5-1.2 \mathrm{ka}$ BP being the absolute minimum in the $\delta^{18} \mathrm{O}$ record. After $\sim 1.2 \mathrm{ka} \mathrm{BP}, \delta^{18} \mathrm{O}$ values increase to $+27.5 \%$ in the most recent sample.

\section{Discussion}

\subsection{Hydrological and meteorological background for the interpretation of the Lake Kotokel diatom isotope record}

In order to assess the recent hydrological background information, the stable isotope composition of Lake Kotokel water as well as that of major rivers connected to Lake Kotokel have been studied in detail (summarized in Table 1 and displayed in a $\delta^{18} \mathrm{O}-\delta \mathrm{D}$ coisotope plot; Fig. 5) and compared to regional precipitation (data from Irkutsk, own samples and GNIP database).

Table 1

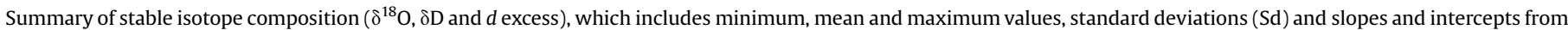
the $\delta^{18} \mathrm{O}-\delta \mathrm{D}$ diagram for the analysed samples representing Lake Kotokel surface water, rain water from Irkutsk and river water connected to Lake Kotokel.

\begin{tabular}{|c|c|c|c|c|c|c|c|c|c|c|c|c|c|c|c|c|c|}
\hline Sample type & $\begin{array}{l}\text { No. } \\
\text { total }\end{array}$ & $\begin{array}{l}T\left[{ }^{\circ} \mathrm{C}\right] \\
\text { Mean }\end{array}$ & $\begin{array}{l}\delta^{18} \mathrm{O}[\%] \\
\operatorname{Min}\end{array}$ & $\begin{array}{l}\delta^{18} \mathrm{O}[\%] \\
\text { Mean }\end{array}$ & $\begin{array}{l}\delta^{18} \mathrm{O}[\%] \\
\operatorname{Max}\end{array}$ & $\begin{array}{l}\delta^{18} \mathrm{O}[\%] \\
\mathrm{Sd}\end{array}$ & $\begin{array}{l}\delta \mathrm{D}\left[\%{ }^{\circ}\right] \\
\operatorname{Min}\end{array}$ & $\begin{array}{l}\delta \mathrm{D}[\%] \\
\text { Mean }\end{array}$ & $\begin{array}{l}\delta \mathrm{D}[\%] \\
\operatorname{Max}\end{array}$ & $\begin{array}{l}\delta \mathrm{D}[\%] \\
\mathrm{Sd}\end{array}$ & $\begin{array}{l}d[\%] \\
\text { Min }\end{array}$ & $\begin{array}{l}d[\%] \\
\text { Mean }\end{array}$ & $\begin{array}{l}d[\%] \\
\operatorname{Max}\end{array}$ & $\begin{array}{l}d[\%] \\
\mathrm{Sd}\end{array}$ & Slope & Intercept & $R^{2}$ \\
\hline $\begin{array}{l}\text { Surface water, } \\
\text { Lake Kotokel }\end{array}$ & 15 & $\begin{array}{l}T_{\text {water }} \\
+24.3\end{array}$ & -13.7 & -12.0 & -10.8 & 0.6 & -113.9 & -106.3 & -101.2 & 3.0 & -14.8 & -10.0 & -4.7 & 2.0 & 4.8 & -48.3 & 0.96 \\
\hline $\begin{array}{l}\text { Inflow rivers, } \\
\text { Lake Kotokel }\end{array}$ & 5 & $\begin{array}{l}T_{\text {water }} \\
+16.5\end{array}$ & -19.5 & -18.8 & -16.9 & 1.1 & -141.5 & -138.1 & -126.2 & 6.7 & 9.1 & 12.3 & 14.5 & 2.0 & 6.2 & -21.2 & 0.99 \\
\hline $\begin{array}{l}\text { Istok/Kotochik } \\
\quad \text { rivers }\end{array}$ & 5 & $\begin{array}{l}T_{\text {water }} \\
+20.6\end{array}$ & -21.8 & -20.9 & -20.2 & 0.7 & -158.8 & -153.6 & -149.5 & 4.0 & 12.0 & 13.4 & 15.3 & 1.5 & 5.8 & -32.9 & 0.99 \\
\hline $\begin{array}{l}\text { Rain water, } \\
\text { Irkutsk }\end{array}$ & 12 & $\begin{array}{l}T_{\text {air }} \\
+14.1\end{array}$ & -14.3 & -10.9 & -5.3 & 3.1 & -113.0 & -85.2 & -52.0 & 21.5 & -9.5 & 2.4 & 12.1 & 6.5 & 6.7 & -11.7 & 0.94 \\
\hline
\end{tabular}


Stable isotope data from the meteorological station in Irkutsk (GNIP database; IAEA, 2001) show that summer air masses reach relatively heavy $\delta^{18} \mathrm{O}$ values of up to $-10 \%$, while winter air masses generally show lighter isotopic composition, which may drop in January and February to $\delta^{18} \mathrm{O}=-25 \%$. The weighted mean annual isotope composition of precipitation in Irkutsk is $\delta^{18} \mathrm{O}=-16.2 \%$, $\delta \mathrm{D}=-124.1 \%$ and $d$ excess $=+5.3 \%$, respectively (IAEA, 2001). Rain samples in Fig. 5 taken in Irkutsk between July and September, 2011 in the frame of this study consequently display the summer season with a mean isotope composition of $\delta^{18} \mathrm{O}=-11 \%$ and $\delta \mathrm{D}=-85 \%$ (mean $d$ excess of $+2.4 \%$ ).

In summer, snow in higher altitudes of the Lake Kotokel hinterland melts and via inflow rivers such as Cheremukhovaya River might drain into the lake. This is underlined by the relatively light isotope composition of the rivers connected with Lake Koto$\mathrm{kel}$. All these rivers connected to Lake Kotokel show a mean isotopic composition of around $-20 \%$ in $\delta^{18} \mathrm{O}$, and $-145 \%$ in $\delta \mathrm{D}$ (mean $d$ excess around $+13 \%$; Table 1 ).

Lake Kotokel is characterized by a mean isotope composition of $-12.0 \%$ in $\delta^{18} \mathrm{O},-106 \%$ in $\delta \mathrm{D}$ and a low mean $d$ excess of $-10 \%$. Thus, the isotopic composition of Lake Kotokel is substantially different from that of the rivers draining to it. All Lake Kotokel samples are situated underneath the Global Meteoric Water Line (GMWL) and linearly correlated in the $\delta^{18} \mathrm{O}-\delta \mathrm{D}$ diagram with a slope of 4.8 and an intercept of $-48\left(r^{2}=0.96\right)$. As this correlation is best explained by evaporative isotope fractionation, it is called an evaporation line (e.g. Gat, 1996, Fig. 5). Evaporation is a disequilibrium fractionation process leading to relative isotope enrichment of heavier isotopes (i.e. higher $\delta^{18} \mathrm{O}$ values) in the lake whereas the lighter isotopes tend to be preferentially evaporated into the vapor phase. The intersection point of the evaporation line with the GMWL (Global Meteoric Water Line; Craig, 1961; or, if available, a Local Meteoric Water Line) is considered to best reflect the original meteoric water prior to evaporative isotope fractionation. The intersection point is at about $-18.5 \%$ for $\delta^{18} \mathrm{O}$ and $-140 \%$ for $\delta \mathrm{D}$ and, hence, similar to the isotopic composition of the inflow rivers, but isotopically lighter than the mean isotopic composition of annual precipitation (mean annual $\delta^{18} \mathrm{O}_{\mathrm{p}}$ in Irkutsk: $-16.2 \%$; GNIP database). This is an additional clue that Lake Kotokel is predominantly fed by snow meltwater from the hinterland and, thus, by precipitation from higher altitudes characterized by lighter $\delta^{18} \mathrm{O}$ and $\delta \mathrm{D}$ values. This also demonstrates that Lake Kotokel water cannot be the origin of any of the rivers i.e. as an outflow (at least in the end of July, 2011), but all rivers drain into the lake. This is surprising because it was assumed that Istok River is fed by Kotokel water and connects Lake Kotokel with Lake Baikal.

In spring, when there is a rapid snow melt (late April - earlyMay), the rivers Kotochik and Turka are filled by meltwater. The water level in Lake Kotokel in this period is lower than the level of Kotochik River in the place where it connects with Istok River (Fig. 1). At this time, water through Istok enters into Lake Kotokel until the levels of Kotokel and Kotochik become identical. This process may continue sometimes until early July. Such water exchange between the Kotokel and Kotochik may occur several times during the summer, depending on the amount of precipitation in the catchments of the lake and Kotochik River (Kozhov, 1939; Egorov, 1950; Khalbaeva and Konnova, 1988). This process was also observed by the authors in 2011. Accordingly, Lake Kotokel is partly a shallow through-flow system (Kozhov, 1950) and partly acts as a closed system.

Additionally, the pathways of atmospheric moisture are an important factor on $\delta^{18} \mathrm{O}_{\mathrm{p}}$. As described in Section 2, two different atmospheric circulation systems supply moisture to the Baikal region, i.e. (1) Atlantic air masses deliver precipitation all year round, whereas (2) south and southeast cyclones are active in July and August. Different air masses carry a characteristic isotopic signal of precipitation (Shemesh et al., 2001; Lee et al., 2003; Rosqvist et al., 2004; Peng et al., 2010). $\delta^{18} \mathrm{O}_{\mathrm{p}}$ is not only a function of the local condensation temperature (Dansgaard, 1964), but also of the history of the air-mass trajectories (Hernandez et al., 2011). Due to the longer atmospheric pathway with subsequent rainout (Rayleigh-distillation type), a greater contribution from the Atlantic air mass would result in a more negative $\delta^{18} \mathrm{O}_{\mathrm{p}}$ as compared to the southern pathway.

In summary, Lake Kotokel is assumed to be fed by meteoric waters, i. e. precipitation with an important contribution of riverine input of snow melt from higher altitudes. Additionally, local moisture can be supplied to Lake Kotokel when evaporation from Lake Baikal takes place. According to Lydolph (1977), evaporation from Lake Baikal tends to be active in November and December. At this time, the smaller Lake Kotokel is already frozen and the diatom bloom period has ended. Therefore, Baikal moisture may reach Lake Kotokel with the snow melt in spring only and has therefore a negligible effect on $\delta^{18} \mathrm{O}$ of the lake water. The shallowness of the lake leads to substantial increase of $T_{\text {lake }}$ in summer. Published data (i.e. Bochkarev and Karnaukhov, 1936; Egorov, 1950; Kozhov, 1950; Khalbaeva and Konnova, 1988; Kuz'mich, 1988) and observations show that maximum lake water temperatures of up to $25^{\circ} \mathrm{C}$ can be reached during the summer period. There is no significant temperature difference between surface and bottom water due to constant wind mixing of the water mass (Antipova and Pomazkova, 1971; Kuz'mich, 1988; Polonnykh, 1988). As the lake is ice-covered between October and May, the blooming period for diatoms is short in summer, but generally offers relatively high surface lake and air temperatures.

Comparing $\delta^{18} \mathrm{O}$ of the lake water of between -10.8 and $-13.6 \%$ (mean: $-12 \%$ ) with the isotopic composition of the most recent diatom $\delta^{18} \mathrm{O}$ in Lake Kotokel of $+27.5 \%\left(\Delta^{18} \mathrm{O}_{\mathrm{SiO}_{2}-\mathrm{H}_{2} \mathrm{O}}\right.$ of 38.3-41.1\%; mean: 39.5\% ), isotope fractionation factors $\alpha$ for the system diatom silica-water are between 1.0417 and 1.0387 (mean $\alpha=1.0400$ ). Using the isotope fractionation correlation between diatom silica and water determined by Juillet-Leclerc and Labeyrie (1987), $T_{\text {lake }}$ is calculated between 11 and $22{ }^{\circ} \mathrm{C}$ (calculated mean $T_{\text {lake }}=16^{\circ} \mathrm{C}$ ) for diatom bloom. Therefore, the isotope composition of diatoms formed in Lake Kotokel might properly reflect the isotope composition of the lake water.

In general, the interpretation of oxygen isotope data from diatom silica in terms of palaeotemperatures requires an understanding of two opposed temperature effects: (1) temperaturedependent fractionation between diatom silica and water as well as (2) the relationship between precipitation and temperature (Leng and Barker, 2006). The water-temperature dependency of oxygen-isotope fractionation for the formation of diatom silica is negative, with published estimates from $\sim-0.5$ to $-0.2 \%$ o ${ }^{\circ} \mathrm{C}$ (Juillet-Leclerc and Labeyrie, 1987; Shemesh et al., 1992; Brandriss et al., 1998; Moschen et al., 2005; Dodd and Sharp, 2010). The lacustrine-based coefficient of $-0.2 \% /{ }^{\circ} \mathrm{C}$ is the most appropriate (Swann and Leng, 2009) and was used for further calculation. Thus, decreasing (increasing) lake temperatures results in larger (smaller) isotope fractionation of the $\delta^{18} \mathrm{O}$ in diatoms compared to the $\delta^{18} \mathrm{O}$ of the water. For Irkutsk precipitation, Seal and Shanks (1998) calculated a positive relationship of $+0.36 \% / 1{ }^{\circ} \mathrm{C}$ between monthly atmospheric air temperature and $\delta^{18} \mathrm{O}_{\mathrm{p}}$ based on the 1990 GNIP data (Morley et al., 2005). As $T_{\text {air }}$ displays stronger variability than $T_{\text {lake, }}$ and has a stronger effect on $\delta^{18} \mathrm{O}_{\text {lake }}, \delta^{18} \mathrm{O}_{\text {diatom }}$ reflects air rather than lake temperatures.

Despite uncertainties about the temporal development of the isotope composition of Lake Kotokel through time, it is assumed that these changes are mainly driven by: (1) changes in $\delta^{18} \mathrm{O}$ of precipitation in the Kotokel catchment. This can be either induced by changes in $T_{\text {air }}$ or by changes of the relative contribution of the 
two main moisture sources, (2) delivery of snow meltwater to the lake as well as by (3) varying evaporative effects. Thus, changes in the isotope composition of the lake are to large parts driven by factors leading to lighter $\delta^{18} \mathrm{O}$ in cold periods and heavier $\delta^{18} \mathrm{O}$ in warm phases.

\subsection{Lake Kotokel diatom species changes and their implications for $\delta^{18} \mathrm{O}_{\text {diatom }}$}

Korde (1968), Polonnykh (1988) and Kuz'mich (1988) demonstrate that $A$. granulata is the dominant species among the diatoms and that the composition of the modern dominant algae complex of Lake Kotokel is stable in recent years. Diatom counts show that species A. granulata also dominates the diatom assemblage through the core reaching a concentration in the Holocene part of the lake sediments of up to $98 \%$ (Bezrukova et al., 2010). Recently, in Lake Kotokel $A$. granulata is the main primary producer in the lake forming a maximum biomass (up to $9.8 \mathrm{~g} / \mathrm{m}^{3}$ ) in late July-early August when the lake is ice-free and nutrients can be supplied to the pool (Antipova and Pomazkova, 1971; Polonnykh, 1988).

The gradual shift in KTK2 $\delta^{18} \mathrm{O}_{\text {diatom }}$ record is accompanied by changes in the diatom species assemblages (Fig. $4 \mathrm{c}-\mathrm{h}$ ). The fossil diatom assemblages during the early Holocene period ( 11.5-9.5 ka BP), are dominated by planktonic A. granulata (up to $506 \times 10^{3}$ valves/g) (Fig. 4d), whereas benthic diatoms (i.e. S. construens agg.) (Fig. 4e) occur at low abundances (about $4-5 \times 10^{3}$ valves $/ \mathrm{g}$ ). This interval is characterized by maximum values of $\delta^{18} \mathrm{O}_{\text {diatom }}(+29.2$ to $+30.3 \%$ ) (Fig. 4a). Between 9.5 and $3 \mathrm{ka} \mathrm{BP}$, a phase of relatively stable $\delta^{18} \mathrm{O}_{\text {diatom values, the diatom assemblages }}$ also reveal rather stable composition and are furthermore dominated by $A$. granulata with moderate abundance of $S$. construens agg. and $S$. pinnata agg. (Fig. 4f). Between $\sim 3$ and 0 ka BP, A. granulata, S. construens agg. and E. arenaria f. teres occur in notable amounts (Fig. $4 \mathrm{~d}$, e and $\mathrm{g}$ ), whereas E. arenaria f. arenaria and S. pinnata agg. (Fig. $4 \mathrm{~h}, \mathrm{f}$ ) are absent. This interval is characterized by lower values of $\delta^{18} \mathrm{O}_{\text {diatom }}$ $(+23.7$ to $+27.5 \%$ ) (Fig. 4a). In most studies (Juillet-Leclerc and Labeyrie, 1987; Shemesh et al., 1995; Brandriss et al., 1998; Schmidt et al., 2001; Moschen et al., 2005; Chapligin et al., 2012) no clear evidence of a species effect in $\delta^{18} \mathrm{O}_{\text {diatom }}$ is found. Only Swann et al. (2008) provide evidence that some form of species effect may exist within $\delta^{18} \mathrm{O}_{\text {diatom }}$ measurements. Despite this, the mechanisms potentially causing these offsets remain unknown (Swann et al., 2008). As there is no clear relationship between the oxygen isotope composition of Lake Kotokel diatoms and their species composition, species effects are not considered to have a significant effect on the isotopic signal. Therefore, the obtained diatom $\delta^{18} \mathrm{O}$ values between $\sim 11.5$ ka BP until today mainly reflect the conditions of $A$. granulata blooms.

\subsection{Holocene diatom oxygen isotope record of the KTK2 core}

Diatom frustules extracted from Lake Kotokel sediment core KTK2 display $\delta^{18} \mathrm{O}_{\text {corr }}$ values between +23.7 and $+30.3 \%$ throughout the Holocene (Fig. 4a). These generally match the range of $\delta^{18} \mathrm{O}$ values of other lacustrine diatom records $(+15$ to $+36 \%$ o (Shemesh et al., 2001; Hu and Shemesh, 2003; Morley et al., 2005; Kalmychkov et al., 2007; Swann et al., 2010).

The Lake Kotokel $\delta^{18} \mathrm{O}_{\text {diatom }}$ record (Fig. 4a) exhibits an overall continuous gradual depletion trend of $\sim 0.35 \% / 1000$ years with a maximum $\delta^{18} \mathrm{O}_{\text {diatom }}$ of about $+30.3 \%$ at $\sim 11.5 \mathrm{ka} \mathrm{BP}$ and a minimum of about $+23.7 \%$ at $\sim 1.2 \mathrm{ka} \mathrm{BP}$. The mean $\delta^{18} \mathrm{O}_{\text {diatom }}$ value (after contamination correction) has been determined to $+28.3 \%$ for the period between $11.5 \mathrm{ka}$ BP and today. The general trend is subdivided into three main time slices (Fig. 4): (KTK2-1) a period of relatively heavy isotope composition of about $+30 \%$ in the early Holocene (between 11.5 and 9.5 ka BP) with a continuously depleting trend of $\sim 1.4 \%$ o 1000 years; (KTK2-2) a relatively stable period between 9.5 and $3 \mathrm{ka} \mathrm{BP}$ with $\delta^{18} \mathrm{O}_{\text {diatom }}$ values around $+28.5 \%$ and only a slight depletion of $\sim 0.2 \% \mathrm{oo} / 1000$ years; (KTK2-3) at $2.7 \mathrm{ka}$ BP a sharp decrease of about $\sim 4 \%$ (to $+24 \%$ ) within about 500 years is observed in the $\delta^{18} \mathrm{O}_{\text {diatom }}$ record. After the absolute minimum $(+23.6 \%$ ) at $\sim 1.2 \mathrm{ka} \mathrm{BP}$, a moderate increase to $+25 \%$ is observed in the $\delta^{18} \mathrm{O}_{\text {diatom }}$ record. The uppermost sample in the Lake Kotokel sediment core $(0-4 \mathrm{~cm})$ has been measured with a $\delta^{18} \mathrm{O}$ of $+27.5 \%$ and gives evidence that the diatom $\delta^{18} \mathrm{O}$ values are in the right order of magnitude (cf. Section 5.1). Additionally, this recent value is in good agreement with the youngest sample from the Lake Baikal core $\left(\delta^{18} \mathrm{O}=+26.6 \%\right.$, after contamination correction $+27.8 \%$; Mackay et al., 2011).

The Lake Kotokel $\delta^{18} \mathrm{O}_{\text {diatom }}$ record is characterized by a marked variability with several single spikes in its isotopic composition (Fig. 4a). In general, the marked variability and single peaks mark either a rapid change in lake hydrology associated with changes in the catchment and/or changes of the precipitation/evaporation ratio.

In the following, all potential controls and the expected relevant changes in $\delta^{18} \mathrm{O}_{\text {diatom }}$ record of Lake Kotokel are discussed. Assuming that the contribution from the different sources of precipitation was constant through the investigated period and considering the total decrease of $6.6 \%$ in $\delta^{18} \mathrm{O}_{\text {diatom }}$ throughout the core (Fig. 6a), an unrealistic increase of $\sim 33{ }^{\circ} \mathrm{C}$ in lake water temperature through the Holocene was calculated. Based on these arguments, the effect of lake water temperature on the $\delta^{18} \mathrm{O}_{\text {diatom }}$ signal is a minor factor to explain variations in $\delta^{18} \mathrm{O}$ records. This allows assuming that the most efficient parameter affecting the Kotokel diatom oxygen isotopic signal is the oxygen isotopic composition of the lake water. Relating the decrease in Lake Kotokel $\delta^{18} \mathrm{O}_{\text {diatom }}$ record solely to air temperature change indicates the direction of the overall decrease of about $7 \%$ in $\delta^{18} \mathrm{O}_{\text {diatom }}$ as a general early to late Holocene cooling trend. Nonetheless, this shift would correspond to about $20 \mathrm{C}^{\circ}$ air temperature change (using the relationship of $+0.36 \% / 2{ }^{\circ} \mathrm{C}$ published by Seal and Shanks, 1998) which is far too high. Thus, most likely Lake Kotokel $\delta^{18} \mathrm{O}_{\text {diatom }}$ changes between $11.5 \mathrm{ka} \mathrm{BP}$ until today reflect changes in the $\delta^{18} \mathrm{O}_{\text {lake }}$ rather than direct air temperature changes.

Therefore, additional factors are needed to explain the variability in the Kotokel diatom isotope record. As introduced above, possible other controls on $\delta^{18} \mathrm{O}$ of Lake Kotokel water are: (1) air mass (direction) changes and changes in seasonal precipitation amounts with time, (2) varying inflow rates and sources including input of isotopically-depleted melt water from the hinterland, as well as (3) evaporative enrichment of the lake water, (4) the duration of the lake ice coverage and (5) lake level changes. The interplay of various factors is necessary to explain the $\delta^{18} \mathrm{O}_{\text {diatom }}$ record of Lake Kotokel.

A change in the relative contribution of the air masses to the local precipitation would influence the isotopic composition of the lake water. If such changes in air mass dominance were persistent through time, they could be reflected in the diatom $\delta^{18} \mathrm{O}$ record. Following this assumption, the general trend could suggest lower relative contribution of Atlantic-dominated continental air masses in the early Holocene ( 11-9 ka BP) as compared to moisture from warmer southeast masses. In the late Holocene to present day, Atlantic air masses would prevail. Changes in the isotope signal of diatoms from Lake Kotokel bottom sediments over time could, thus, be interpreted as reflecting regional variations in atmospheric circulation. However, such changes in air-mass trajectories should, with a certain lag, also be visible at Lake Baikal.

Evaporation has a significant effect on the isotopic composition of the residual water (Craig and Gordon, 1965) especially in a relatively shallow lake such as Lake Kotokel. As evaporation of lake 


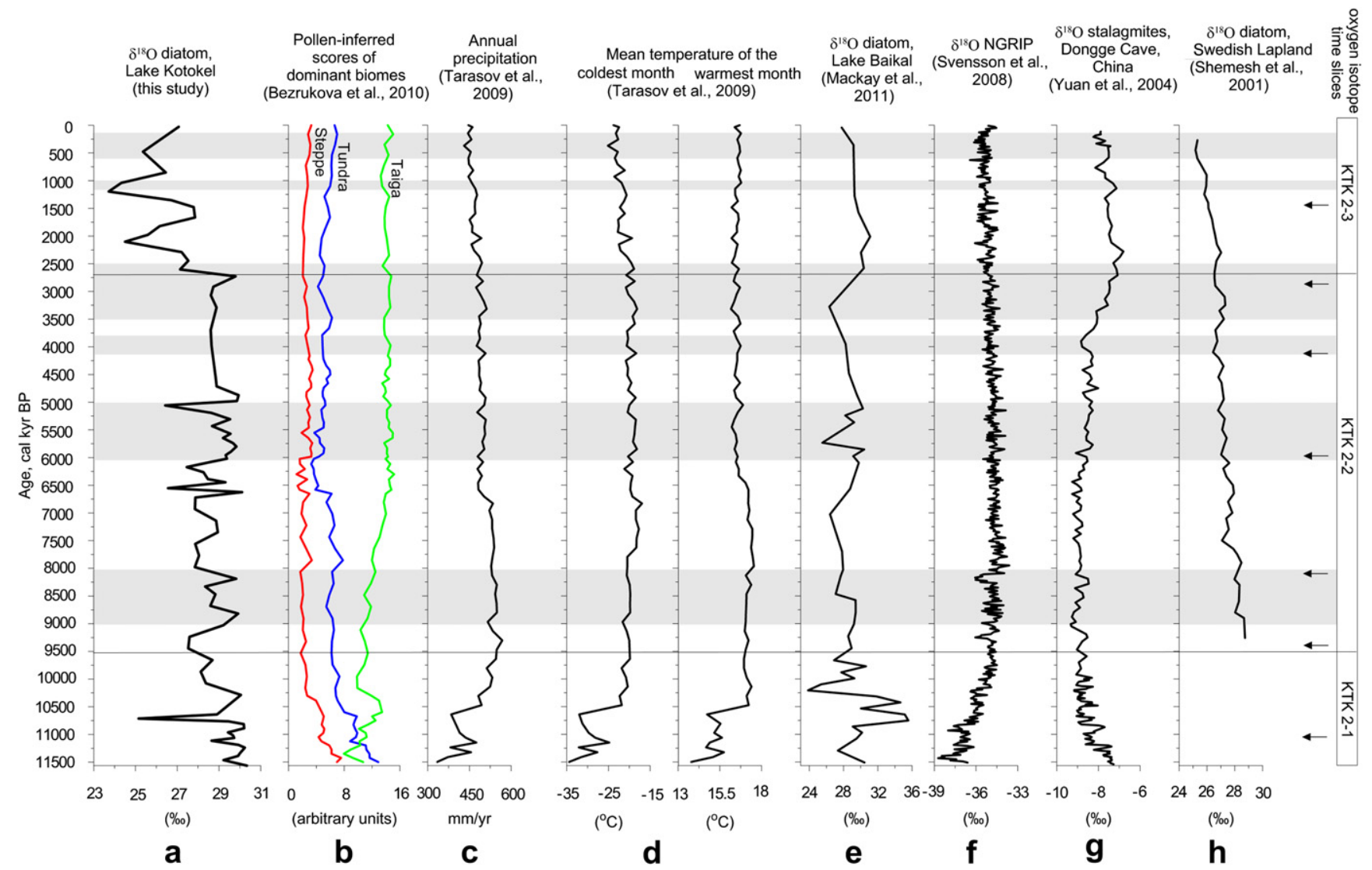

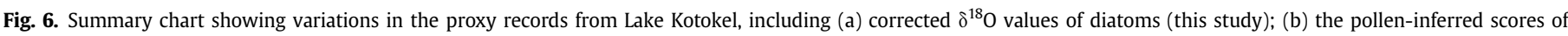

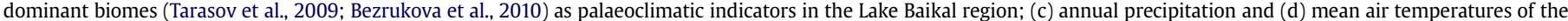

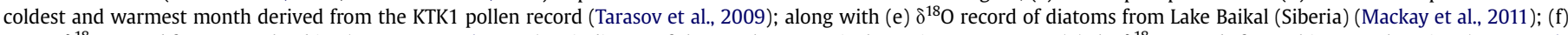

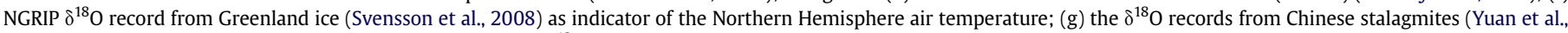

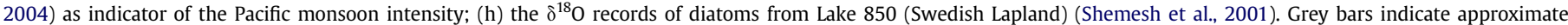

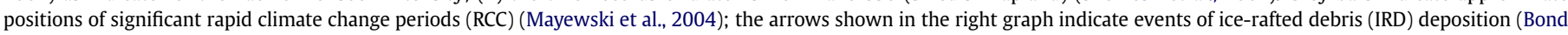
et al., 1997).

water leads to an isotopic enrichment of heavy isotopes in the lake, this would be reflected in higher $\delta^{18} \mathrm{O}_{\text {diatom }}$ values. Consequently, enhanced evaporative enrichment should be notable as a positive shift in the diatom isotope record.

Inflow due to meltwater input is an important control on lake water $\delta^{18} \mathrm{O}$ (Leng et al., 2001). Enhanced melting of perennial snowfields or isolated ice caps in the hinterland of Lake Kotokel may act as an important source of low $\delta^{18} \mathrm{O}$ in water, whereas the build-up of these forms in colder times may reduce meltwater supply of lighter isotopic composition to the lake until the system has reached a new steady state. This is counter-intuitive because a warming would favour higher $\delta^{18} \mathrm{O}$ in precipitation (Dansgaard, 1964) and enhanced evaporation would lead to even higher $\delta^{18} \mathrm{O}$ in the lake. Melting events should follow a regional warming, lead to enhanced nutrient supply and, thus, a higher diatom concentration in the core. In the Lake Kotokel oxygen isotope record,

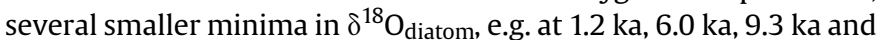
$10.8 \mathrm{ka}$ BP correspond roughly to maxima in the diatom concentration (Fig. 5a, c). A sudden drop in $\delta^{18} \mathrm{O}$ accompanied by increased diatom concentration may, thus, reflect a meltwater pulse as a reaction to temperature increase. The duration of the summer season (and hence the persistence of the lake-ice-cover) is another crucial factor influencing diatom blooming period with its respective $T_{\text {lake. }}$ Hence, a clue to the regional interpretation of the Lake Kotokel $\delta^{18} \mathrm{O}$ record (Fig. 6a) is the comparison to the nearby Lake Baikal $\delta^{18} \mathrm{O}$ data (Mackay et al., 2011, Fig. 6e).

\subsection{Inter- and extra-regional comparison}

The pattern of the $\delta^{18} \mathrm{O}_{\text {diatom }}$ record in the Holocene part of the KTK2 core shows partly similarities, and partly differs considerably from that obtained from the Lake Baikal. Between 11.5 and $10.3 \mathrm{ka} \mathrm{BP}$, both records are characterized by highest $\delta^{18} \mathrm{O}_{\text {diatom }}$ values (Baikal: $\delta^{18} \mathrm{O}+35 \%$; Kotokel: $+30 \%$ ). However, the first $\sim 700$ years of the Holocene are accompanied by opposite trends in $\delta^{18} \mathrm{O}_{\text {diatom }}$ of both records. Whereas at Lake Baikal, $\delta^{18} \mathrm{O}_{\text {diatom }}$ increases about $3 \%$, at Lake Kotokel a decrease in $\delta^{18} \mathrm{O}_{\text {diatom values }}$ is observed. Both records show rather constant $\delta^{18} \mathrm{O}_{\text {diatom }}$ values around $+28 \%$ between 9 and 3 ka BP. However, after 3 ka BP, both $\delta^{18} \mathrm{O}_{\text {diatom }}$ records again show roughly opposite trends (Fig. 6a, e). Only a slight gradual enrichment of the $\delta^{18} \mathrm{O}_{\text {diatom }}$ record through the Holocene is observed for Lake Baikal (Kalmychkov et al., 2007; Mackay et al., 2011), while diatoms from Lake Kotokel show a continuous gradual depletion in $\delta^{18} \mathrm{O}_{\text {diatom }}$ since the early Holocene. This is most likely due to the significant differences in the hydrological setting of both lakes, whereas the general climatic conditions and main atmospheric patterns are similar. Lake Baikal is a very large and deep-water body, whereas Lake Kotokel is a relatively small shallow lake. The residence time of Lake Baikal is about 400 years (Gronskaya and Litova, 1991), thus $>50$ times larger than that estimated for Lake Kotokel (7 years; Shichi et al., 2009). Lake Baikal is remarkably uniform in its oxygen isotope composition of water averaging to $\delta^{18} \mathrm{O}_{\mathrm{w}}=-15.8 \pm 0.2 \%$ (Seal and 
Shanks, 1998). Water is supplied to Lake Baikal from more than 300 rivers and streams (Kozhov, 1955), with variable oxygen isotope composition ranging from -13.4 to $-21.2 \%$ (Seal and Shanks, 1998). Hence, changes in $\delta^{18} \mathrm{O}_{\text {diatom }}$ from Lake Baikal sediments have been linked to variations in fluvial input, most notably between rivers with catchments which extend to the south of Lake Baikal into Mongolia (i. e. $\delta^{18} \mathrm{O}=-13.5 \%$ for Selenga River; Seal and Shanks, 1998) and rivers with more northerly $\left(\delta^{18} \mathrm{O}=-19.5 \%\right.$ for Upper Angara; Seal and Shanks, 1998) catchments (Morley et al., 2005; Mackay et al., 2008, 2011). However, in the lower part, $\delta^{18} \mathrm{O}_{\text {diatom }}$ values from Baikal Lake have been corrected strongly (for more than 60\% contamination between 11 and $10 \mathrm{ka} \mathrm{BP}$ ) and have larger error bars. In the past $5 \mathrm{ka}$, contamination correction is considerably lower (for $<20 \%$ contamination; Mackay et al., 2011). Diatom dissolution is a significant process in Lake Baikal (Ryves et al., 2003; Battarbee et al., 2005). It has been shown that some diatom species may partly dissolve in the water column, as well as at the sediment-water interface for other more robust taxa. It has been suggested that only $1 \%$ of the valves are finally preserved in the Lake Baikal sedimentary record (Ryves et al., 2003; Battarbee et al., 2005). Swann et al. (2005) were unable to make a positive identification of some diatom species due to their dissolution. Dissolution effects need to be taken into account in environmental reconstructions.

In contrast, Lake Kotokel is characterized by a heavier average oxygen isotope composition of $-12 \%$. Rivers connected to Lake Kotokel as mentioned above have a mean $\delta^{18} \mathrm{O}$ around $-20 \%$. Here, evaporation plays a major role in controlling changes on lake water $\delta^{18} \mathrm{O}$ and, thus, on the Kotokel diatom $\delta^{18} \mathrm{O}$ record. Due to the shallowness of Lake Kotokel and the good preservation of Kotokel diatoms under the REM, dissolution effects are less significant than for Lake Baikal.

Bezrukova et al. (2010) note that an obvious shift to the Holocene interglacial environments appears in the Kotokel diatom and pollen records at $\sim 11.7-11.6 \mathrm{ka} B P$, suggesting an almost synchronous response of terrestrial and aquatic ecosystems to global climate change. This date agrees with the formal definition and dating of the Global Stratotype Section for the base of the Holocene ( $\sim 11,650$ cal y BP), derived from the Greenland NGRIP ice core and selected regional records (Walker et al., 2009), pointing to a synchronous onset of the Holocene interglacial across Eurasia (Bezrukova et al., 2010). According to pollen data a gradual increase is marked both in precipitation amount (Fig. 6c) as well as in winter and summer temperatures between 11.5 and 9.5 ka BP (Fig. 6d; Bezrukova et al., 2010), also detected in the NGRIP record (Svensson et al., 2008, Fig. 6f). Bezrukova et al. (2011) determined vegetation changes at the onset of the Holocene, which were likely caused by the global climatic warming. The beginning of the Holocene is accompanied by a gradual decrease of $\delta^{18} \mathrm{O}$ values of Lake Kotokel diatom from $+30.3 \%$ at $11.5 \mathrm{ka}$ BP to $+27.5 \%$ at $9.5 \mathrm{ka}$ BP interrupted by an abrupt event to $+25.2 \%$ at $10.7 \mathrm{ka}$ BP. As a decrease in $\delta^{18} \mathrm{O}_{\text {diatom }}$ of Lake Kotokel during this period is accompanied by an increase in air temperatures (derived from the pollen and NGRIP data), $T_{\text {air }}$ cannot be the determining factor, because it is positively correlated with $\delta^{18} \mathrm{O}_{\mathrm{p}}$. Therefore, during this interval Lake Kotokel received less precipitation and acted as a closed-system basin during longer periods per year. Consequently, enhanced evaporation can explain the highest $\delta^{18} \mathrm{O}$ values between 11.5 and $9.5 \mathrm{ka} \mathrm{BP}$. The gradual decrease in $\delta^{18} \mathrm{O}_{\text {diatom }}$ in that period is in line with increasing precipitation rates, rising air temperatures and, potentially enhanced meltwater influx from perennial snowfields or isolated ice caps in the hinterland of Lake Kotokel.

Numerous palaeoclimate studies based on high-resolution proxy records demonstrate that Holocene climate has not been stable (Mayewski et al., 2004; Wanner et al., 2008). The obtained oxygen isotope record from Lake Kotokel also shows that the Holocene has been a period of rapid and variable climate change. Based on studies of palaeoclimatic records from the northern and southern hemispheres, Mayewski et al. (2004) identified six periods of significant rapid climate change (RCC) during the time periods $9000-8000$, 6000-5000, 4200-3800, 3500-2500, 1200-1000, and 600-150 cal yr BP, which are characterised by polar cooling, humidity change in the tropics, and major atmospheric circulation changes. These RCCs are generally marked by strengthened atmospheric circulation over the North Atlantic and Siberia (except the shorted RCCs at 4200-3800 and 1200-1000 cal yr BP; Mayewski et al., 2004) and should be visible as minima or decrease in the Kotokel isotope record.

However, the time period $9-8 \mathrm{ka}$ BP is marked in the Kotokel isotope record by two maxima at 8.8 and $8.2 \mathrm{ka} \mathrm{BP} \mathrm{(Fig.} \mathrm{6a)} \mathrm{with}$ $\delta^{18} \mathrm{O}$ values of 29.9 and $29.8 \%$, respectively. According to the isotope data the time period between 6 and $5 \mathrm{ka} \mathrm{BP}$ was rather stable with the exception of the sharp $\delta^{18} \mathrm{O}$ variations from +29.5 to $+26.4 \%$ at $\sim 5.3-5.1$ ka BP (Fig. 6a). Around 5.7 ka BP, a minimum in the $\delta^{18} \mathrm{O}_{\text {diatom }}$ signal is observed in the Baikal record (Fig. 6e), which has been attributed to decreasing fluvial input to Lake Baikal (Mackay et al., 2011). In contrast, the climate reconstructions from KTK1 pollen record demonstrate rather constant precipitation and air temperatures at this time (Fig. 6c, d). In the Lake Kotokel isotope record in the interval corresponding to $3.5-2.5 \mathrm{ka}$ BP there has been a gradual increase in the $\delta^{18} \mathrm{O}$ values to $+29.8 \%$ at $\sim 2.7 \mathrm{ka} \mathrm{BP}$, and a sharp drop to $+27.1 \%$ at $\sim 2.6 \mathrm{ka}$ BP. The results of pollen analysis show a decline in the index of the taiga, precipitation and winter temperatures during this period (Fig. $6 \mathrm{~b}-\mathrm{d}$ ). A sharp decline of $\delta^{18} \mathrm{O}_{\text {diatom values from }+27.8 \% \text { at }}$ $\sim 1.5 \mathrm{ka}$ BP to +23.7 or $+24.3 \%$ at $1.2-1 \mathrm{ka}$ BP is observed in the oxygen isotope curve obtained for Lake Kotokel. According to pollen-based reconstruction (Tarasov et al., 2009) the decline in amount of annual precipitation and in winter and summer temperatures is marked during this period (Fig. 6c, d).

Comparison of the timing of enhanced ice-rafted debris (IRD) deposition and low surface water temperatures (Bond et al., 1997) in the North Atlantic (peaks at about 1.4, 2.8, 4.2, 5.9, 8.1, 9.4, 10.3 and $11.1 \mathrm{ka} \mathrm{BP}$ ) with changes in the oxygen isotope composition of diatoms from Lake Kotokel sediments also suggests that the IRD events in the North Atlantic might show a response in the Lake Kotokel isotopic record. All these dates are marked by visible changes in the isotopic composition of diatoms: the events of 10.3, 8.1, 5.9, 2.8, $1.4 \mathrm{ka} \mathrm{BP}$ in the isotope curve are marked by elevated values of $\delta^{18} \mathrm{O}_{\text {diatom }}$ (Fig. 6a). A decline in $\delta^{18} \mathrm{O}_{\text {diatom values of } 1.2 \text { and }}$ $1.3 \%$ are observed at $\sim 9.4$ and $\sim 11.1 \mathrm{ka}$ BP, respectively. However, the mechanism behind the influence of IRD events on $\delta^{18} \mathrm{O}_{\text {diatom }}$ is unclear still.

The synchronicity of climate events in the Kotokel isotope record and the sequence of North Atlantic cooling events suggest that the large-scale climatic shifts in the North Atlantic region might have influenced the Lake Kotokel diatom isotope composition. The character of the isotope record obtained for Lake Kotokel is similar to that obtained for Swedish Lapland (Lake 850: Shemesh et al., 2001; Vuolep Allakasjaure: Rosqvist et al., 2004). All curves show a general depletion trend in $\delta^{18} \mathrm{O}$ values through the core (Fig. 6a, h). This depletion for Swedish Lapland diatoms is interpreted as an increase in the influence of the Arctic polar continental air mass that carries isotopically-depleted precipitation (Shemesh et al., 2001) and corresponds with IRD maxima (Rosqvist et al., 2004). Assuming that isotopically-depleted precipitation reaches the Lake Kotokel region with a western Atlantic air mass drift, lower $\delta^{18} \mathrm{O}_{\text {diatom }}$ suggests a greater contribution from the colder Atlantic mass. However, such a larger scale climatic change needs to be also detected with a lag time of several hundred years in the $\delta^{18} \mathrm{O}$ 
diatom record from Lake Baikal (Fig. 6e). As this continuous depletion is not visible at Lake Baikal, the precipitation change was either small or without notable effect in the region.

In general, the diatom $\delta^{18} \mathrm{O}$ record from Lake Kotokel resembles the stalagmites $\delta^{18} \mathrm{O}$ record from Dongge Cave (China) (Fig. 6a, g). Both curves demonstrate a gradual depletion trend during the early Holocene, then relatively stable conditions from about 9 to $3 \mathrm{ka} \mathrm{BP}$ and a marked change at $\sim 3-2.5 \mathrm{ka} \mathrm{BP}$ with depletion in both $\delta^{18} \mathrm{O}$ records. The East Asian summer monsoon activity was enhanced shortly after the Younger Dryas (YD) at the onset of the Holocene, and was strongest in the early and mid-Holocene, and weakened after the mid-Holocene (Chen et al., 2008; Wang et al., 2012). The $\delta^{18} \mathrm{O}$ records from Chinese stalagmites are interpreted as an indicator of the Pacific monsoon intensity (Tarasov et al., 2009; Bezrukova et al., 2010), and, thus, might be an indicator of moisture deriving from the southeast, even though monsoonal circulation did not reach the Baikal area directly. The similarity in the temporal distribution of $\delta^{18} \mathrm{O}$ values for stalagmites and diatoms suggests that the oxygen isotope record from Lake Kotokel can serve as an indicator of air masses entering the region from the southeast, which could be prevalent especially in early to mid Holocene times.

The Lake Kotokel records presented in this paper are linked to changes in the northern hemispheric climate, which are responsible for the sub-latitudinal transport of heat and moisture to the central parts of Eurasia. The $\delta^{18} \mathrm{O}_{\text {diatom }}$ record of Lake Kotokel in comparison with climate records from other regions not only reflects global climatic changes but also accounts for regional climatic features. This demonstrates the complexity of the interplay of different controls for the regional climatic conditions between site-specific factors such as hydrology (water volume, residence time, evaporation, inflow of snow melt) superimposing general, i.e. northern hemisphere climatic trends. This study underlines the importance of oxygen isotope analyses in fresh-water diatoms for palaeoclimatic investigations.

\section{Conclusions}

Diatom biogenic silica isotope records from the KTK2 core of Lake Kotokel, near Lake Baikal provide important information on Holocene climatic and environmental changes. The fractionation between recent Lake Kotokel water and the most recent diatom sample is in the right order of magnitude (mean $\alpha=1.0400$ ), and allows calculating reasonable water temperatures. Nonetheless, the $\delta^{18} \mathrm{O}$ in Kotokel diatoms is predominantly controlled by $\delta^{18} \mathrm{O}$ of the lake and not by the lake water temperature. Main controls influencing on $\delta^{18} \mathrm{O}_{\text {lake }}$ are $\delta^{18} \mathrm{O}_{\mathrm{p}}$ (thus $T_{\text {air }}$ ) as well as evaporation effects.

The region around Lake Kotokel has undergone significant climatic and environmental changes through the Holocene. The presented downcore oxygen isotope record indicates that the temperature history in the Lake Kotokel region during the last 11.5 ka has generally followed the northern hemisphere temperature trends described in other records, i. e. late to mid-Holocene cooling after the Holocene Optimum. Meltwater release from the hinterland was detected as minima in the $\delta^{18} \mathrm{O}$ record of Lake Kotokel corresponding with maxima in the diatom concentration. Especially the combination of $\delta^{18} \mathrm{O}_{\text {diatom }}$ and pollen data helps differentiate regional and global events and response of the vegetation to these changes in more detail. Due to the similar regional setting and climate, but a different hydrology, the combination with Lake Baikal $\delta^{18} \mathrm{O}$ record leads to an improved understanding of the regional and northern hemispheric components contained in the Lake Kotokel $\delta^{18} \mathrm{O}$ signal.

As demonstrated, the overall trend in the diatom isotope signal from Lake Kotokel sediments in the Holocene correspond with regional variations in atmospheric circulation. Especially in the early Holocene, $\delta^{18} \mathrm{O}_{\text {lake }}$ is rather influenced by moisture-carrying air masses from the south east, likely further enriched in ${ }^{18} \mathrm{O}$ and superimposed by enhanced evaporation. In the late Holocene, colder climatic conditions with lower evaporation prevail and the relative influence of Atlantic-derived moisture seems to be stronger. Future studies on the seasonal change of lake water isotope composition are aimed to better understand the isotope geochemistry of Lake Kotokel and its hydrological system.

\section{Acknowledgements}

This study was first planned during an International Workshop "Bridging Eurasia" (German Research Foundation (DFG) grant TA540/4) held at FU Berlin in May 2010 and is a contribution to the DFG Priority Program 'INTERDYNAMIC' (grant TA-540/1) and to the Baikal-Hokkaido Archaeology Project. The study was also partly supported by the Russian Foundation for Basic Research (RFBR), grant 12-05-00476 and by the DFG grant Me-3266-3-1. The authors would like to thank Helga Kemnitz and Rudolph Naumann from the German Research Center for Geosciences (GFZ) for their SEM and XRD support. Additional thanks are owed to Yury Didenkov from Irkutsk State Technical University (ISTU) for discussions on hydrological regime of Lake Kotokel.

\section{References}

Alpat'ev, A.M., Arkhangel'skii, A.M., Podoplelov, N.Y., Stepanov, A.Y., 1976. Fizicheskaya Geografiya SSSR (Aziatskaya Chast'). Vysshaya Shkola, Moscow (in Russian).

Antipin, V., Afonina, T., Badarov, O., Bezrukova, E., Bukharov, A., Bychinsky, V., Dmitriev, A.A., Dorofeeva, R., Duchkov, A., Esipko, O., Fileva, T., Gelety, V., Golubev, V., Goreglyad, A., Gorokhov, I., Gvozdkov, A., Hase, Y., Ioshida, N. Ivanov, E., Kalashnikova, I., Kalmychkov, G., Karabanov, E., Kashik, S., Kawai, T., Kerber, E., Khakhaev, B., Khlystov, O., Khursevich, G., Khuzin, M., King, J., Konstantinov, K., Kochukov, V., Krainov, M., Kravchinsky, V., Kudryashov, N., Kukhar, L., Kuzmin, M., Nakamura, K., Nomura, Sh., Oksenoid, E., Peck, J., Pevzner, L., Prokopenko, A., Romashov, V., Sakai, H., Sandimirov, I., Sapozhnikov, A., Seminsky, K., Soshina, N., Tanaka, A., Tkachenko, L., Ushakovskaya, M., Williams, D., 2001. The new BDP-98 600-m drill core from Lake Baikal: a key late Cenozoic sedimentary section in continental Asia. Quaternary International 80-81, 19-36.

Antipova, N.L., Pomazkova, G.I., 1971. O planktone oz. Kotokel. Issledovanie gidrobiologicheskogo rezhima vodoemov Vostochnoi Sibiri, Irkutsk, pp. 27-39 (in Russian).

Battarbee, R.W., Jones, V.J., Flower, R.J., Cameron, N.G., Bennion, H., Carvalho, L., Juggins, S., 2001. Diatoms. In: Smol, J.P., Birks, H.J.B., Last, W. (Eds.), 2001 Tracking Environmental Change Using Lake Sediments, vol. 3. Kluwer Academic Publishers, Dordrecht, pp. 155-202.

Battarbee, R.W., Mackay, A.W., Jewson, D.H., Ryves, D.B., Sturm, M., 2005. Differential dissolution of Lake Baikal diatoms: correction factors and implications for palaeoclimatic reconstruction. Global and Planetary Change 46, 75-86.

Bezrukova, E.V., Krivonogov, S.K., Takahara, H., Letunova, P.P., Shichi, K., Abzaeva, A.A., Kulagina, N.V., Zabelina, Yu.S., 2008. Lake Kotokel as a Stratotype for the Late Glacial and Holocene in Southeastern Siberia. Doklady Earth Sciences 420 (4), 658-663.

Bezrukova, E.V., Tarasov, P.E., Solovieva, N., Krivonogov, S.K., Riedel, F., 2010. Last glacial-interglacial vegetation and environmental dynamics in southern Siberia: chronology, forcing and feedbacks. Palaeogeography, Palaeoclimatology, Palaeoecology 296, 185-198.

Bezrukova, E.V., Tarasov, P.E., Kulagina, N.V., Abzaeva, A.A., Letunova, P.P., Kostrova, S.S., 2011. Palynological study of Lake Kotokel' bottom sediments. Russian Geology and Geophysics 52, 457-464.

Bochkarev, P.F., Karnaukhov, A.S., 1936. Gidrokhimicheskoe issledovanie oz. Kotokel. Izvestiya BGNII pri Vostochnosibirskom Gosudarstvennom Universitete 8 (1-2), 68-69 (in Russian).

Bond, G., Showers, W., Cheseby, M., Lotti, R., Almasi, P., deMenocal, P., Priore, P., Cullen, H., Hajdas, I., Bonani, G., 1997. A pervasive Millennial-Scale Cycle in North Atlantic Holocene and glacial climates. Science 278, 1257-1266.

Brandriss, M.E., O'Neil, J.R., Edlund, M.B., Stoermer, E.F., 1998. Oxygen isotope fractionation between diatomaceous silica and water. Geochimica et Cosmochimica Acta 62, 1119-1125.

Brauer, A., Mangili, C., Moscariello, A., Witt, A., 2008. Palaeoclimatic implications from micro-facies data of a 5900 varve time series from the Piànico interglacial sediment record, southern Alps. Palaeogeography, Palaeoclimatology, Palaeoecology 259, 121-135.

Brewer, T.S., Leng, M.J., Mackay, A.W., Lamb, A.L., Tyler, J.J., Marsh, N.G., 2008. Unravelling contamination signals in biogenic silica oxygen isotope 
composition: the role of major and trace element geochemistry. Journal of Quaternary Science 23 (4), 321-330.

Chapligin, B., Meyer, H., Friedrichsen, H., Marent, A., Sohns, E., Hubberten, H.-W. 2010. A high-performance, safer and semi-automated approach for the $\delta^{18} \mathrm{O}$ analysis of diatom silica and new methods for removing exchangeable oxygen. Rapid Communications in Mass Spectrometry 24, 2655-2664.

Chapligin, B., Leng, M.J., Webb, E., Alexandre, A., Dodd, J.P., Ijiri, A., Lücke, A., Shemesh, A., Abelmann, A., Herzschuh, H., Longstaffe, F.J., Meyer, H., Moschen, R., Okazaki, Y., Rees, N.H., Sharp, Z.D., Sloane, H.J., Sonzongi, C., Swann, J.E.A., Sylvestre, F., Tyler, J.J., Yam, R., 2011. Inter-laboratory comparison of oxygen isotope compositions from biogenic silica. Geochimica et Cosmochimica Acta 75, 7242-7256.

Chapligin, B., Meyer, H., Bryan, A., Snyder, J., Kemnitz, H., 2012. Assessment of purification and contamination correction methods for analysing the oxygen isotope composition from biogenic silica. Chemical Geology 300-301, 185-199.

Chen, F., Yu, Z., Yang, M., Ito, E., Wang, S., Madsen, D.B., Huang, X., Zhao, Y., Sato, T. Birks, H.J.B., Boomer, I., Chen, J., An, Ch., Wünnemann, B., 2008. Holocene moisture evolution in arid central Asia and its out-of-phase relationship with Asian monsoon history. Quaternary Science Reviews 27, 351-364.

Clayton, R., Mayeda, T., 1963. The use of bromine pentafluoride in the extraction of oxygen from oxides and silicates for isotopic analysis. Geochimica et Cosmochimica Acta 27, 43-52.

Colman, S.M., Jones, G.A., Rubin, M., King, J.W., Peck, J.A., Orem, W.H., 1996. AMS radiocarbon analyses from Lake Baikal, Siberia: challenges of dating sediments from a large, oligotrophic lake. Quaternary Science Reviews 15, 669-684.

Craig $H$, 1961. Isotopic variations in meteoric waters. Science 133, 1702-1703.

Dansgaard, W., 1964. Stable isotopes in precipitation. Tellus 16, 436-468.

Demske, D., Heumann, G., Granoszewski, W., Nita, M., Mamakowa, K., Tarasov, P.E., Oberhansli, H., 2005. Late glacial and Holocene vegetation and regional climate variability evidenced in high-resolution pollen records from Lake Baikal. Global and Planetary Change 46, 255-279.

Dodd, J.P., Sharp, Z.D., 2010. A laser fluorination method for oxygen isotope analysis of biogenic silica and a new oxygen isotope calibration of modern diatoms in freshwater environments. Geochimica et Cosmochimica Acta 74, 1381-1390.

Egorov, A.G., 1950. Ozero Kotokel. Izvestiya BGNII Pri Irkutskom Universitete 11 (1), 3-38 (in Russian).

Galaziy, G.I. (Ed.), 1993. Baikal Atlas. Federal Agency for Geodesy and Cartography of Russia, Moscow (in Russian)

Gat, J.R., 1996. Oxygen and hydrogen isotopes in the hydrological cycle. Annual Review of Earth and Planetary Sciences 24, 225-262.

Gómez, N., Riera, J.L., Sabater, S., 1995. Ecology and morphological variability of Aulacoseira granulata (Bacillariophyceae) in Spanish reservoirs. Journal of Plankton Research 17 (1), 1-16.

Craig, H., Gordon, L.I., 1965. Deuterium and oxygen-18 variations in the ocean and the marine atmosphere. Marine Geochemistry 3, 277-374.

Gronskaya, T.P., Litova, T.E., 1991. Kratkaya harakteristika vodnogo balansa ozera Baikal za period 1962-1988 (Short characteristics of the water balance of Lake Baikal during 1962-1988). In: Izrael, Y.A., Anokhin, Y.A. (Eds.), Monitoring Okruzhayuschei Sredy Osera Baikal (Monitoring of Lake Baikal Environment) Gidrometeoizdsat, Leningrad, pp. 153-158 (in Russian).

Gustokashina, N.N., 2003. Long-Term Variations in Basic Climate Elements on the Cisbaikalia Territory. Institute of Geography Sibirskoe Otdelenie RAS, Irkutsk (in Russian).

Haimson, M., Knauth, L.P., 1983. Stepwise fluorination-a useful approach for the isotopic analysis of hydrous minerals. Geochimica et Cosmochimica Acta 47, 1589-1595.

Hernandez, A., Bao, R., Giralt, S., Barker, P.A., Leng, M.J., Sloane, H.J., Sáez, A., 2011. Biogeochemical processes controlling oxygen and carbon isotopes of diatom silica in Late Glacial to Holocene lacustrine rhythmites. Palaeogeography, Palaeoclimatology, Palaeoecology 299, 413-425.

Hövsgöl Drilling Project Group, Abzaeva, A.A., Bezrukova, E.V., Bychinsky, V.A Fedenya, S.A., Geletiy, V.F., Goreglyad, A.V., Ivanov, E.V., Inoue, G., Kawai, T., Kalmychkov, G.V., Kashiwaya, K., Kerber, E.V., Khomutova, M.Yu, Khursevich, G.K., Krainov, M.A., Kuzmin, M.I., Kulagina, N.V., Letunova, P.P., Minoura, K., Narantsetseg, Ts., Osukhovskaya, Yu.V., Oyunchimeg, Ts. Prokopenko, A.A., Sakai, H., Solotchina, E.P., Tkachenko, L.L., Tomurhuu, D., 2007. Structure of bottom sediments in lake Hövsgöl: geological and climate control. Russian Geology and Geophysics 48, 863-885.

Hu, F.Sh., Shemesh, A., 2003. A biogenic-silica $\delta^{18}$ O record of climatic change during the last glacial-interglacial transition in southwestern Alaska. Quaternary Research 59, 379-385.

IAEA, 2001. GNIP Maps and Animations. International Atomic Energy Agency, Vienna. http://isohis.iaea.org.

Jones, M.D., Roberts, C.N., 2008. Interpreting lake isotope records of Holocene environmental change in the Eastern Mediterranean. Quaternary International $181,32-38$.

Jones, V.J., Leng, M.J., Solovieva, N., Sloane, H.J., Tarasov, P., 2004. Holocene climate of the Kola Peninsula; evidence from the oxygen isotope record of diatom silica. Quaternary Science Reviews 23, 833-839.

Juillet-Leclerc, A., Labeyrie, L., 1987. Temperature dependence of the oxygen isotopic fractionation between diatom silica and water. Earth and Planetary Science Letters 84, 69-74.

Kalmychkov, G.V., Kostrova, S.S., Geletii, V.F., Tkachenko, L.L., Rakhlin, V.I., 2005. Method of separation of diatom frustules from bottom sediments for oxygen isotopic analysis and paleoclimatic reconstruction. Geochemistry International 43 (12), 1252-1254.

Kalmychkov, G.V., Kuz'min, M.I., Pokrovskii, B.G., Kostrova, S.S., 2007. Oxygen isotopic composition in diatom algae frustules from Lake Baikal sediments: annual mean temperature variations during the last $40 \mathrm{Ka}$. Doklady Earth Sciences 413 (2), 206-209.

Kashutina, M.V., Ioffe, S.A., Tartakovskii, V.A., 1975. Silylation of organic compounds. Uspechi Khimii 44 (9), 1620-1648 (in Russian).

Khalbaeva, T.V., Konnova, R.P., 1988. Physico-geographycheskaya kharacteristika ozer Irkana i Kotokel. Sbornik Nauchnih Trudov GosNIOPH 279, 5-16 (in Russian).

Korde, N.V., 1968. Mesozoic and Cenozoic Lakes of Siberia. Nauka. Moscow (in Russian).

Kossler, A., Tarasov, P., Schlolaut, G., Nakagawa, T., Marshall, M., Brauer, A., Staff, R. Bronk Ramsey, C., Bryant, C., Lamb, H., Demske, D., Gotanda, K., Haraguchi, T., Yokoyama, Y., Yonenobu, H., Tada, R., Suigetsu 2006 project members, 2011. Onset and termination of the late-glacial climate reversal in the high-resolution diatom and sedimentary records from the annually laminated SG06 core from Lake Suigetsu, Japan. Palaeogeography, Palaeoclimatology, Palaeoecology 306, 103-115.

Kozhov, M.M., 1939. Ozero Kotokel (gidrobiologicheskyi ocherk). Izvestiya Biologogeographicheskogo Instituta Pri Irkutskom Yniversitete 8 (1-2), 120-147 (in Russian).

Kozhov, M.M., 1950. Presnie vodi Vostochnoi Sibiri. Irkutsk (in Russian).

Kozhov, M.M., 1955. Baikal i ego zhizn':(nauchno-popularnyi ocherk). Knizhnoe izdatelstvo, Irkutsk, pp. 44 (in Russian).

Kurita, N., Yoshida, N., Inoue, G., Chayanova, E.A., 2004. Modern isotope climatology of Russia: a first assessment. Journal of Geophysical Research 109 (D03102), $1-15$.

Kuz'mich, V.N., 1988. Ecologo-produksionnaya kharakteristika ozer Irkana i Kotokel. Sbornik Nauchnih Trudov GosNIOPH 279, 131-146 (in Russian).

Labeyrie, L.D., 1974. New approach to surface seawater palaeotemperatures using ${ }^{18} \mathrm{O} /{ }^{16} \mathrm{O}$ ratios in silica of diatom frustules. Nature $248,40-42$

Ladeischikov, N.P. (Ed), 1977. Struktura i resursi klimata Baikala i sopredel'nih prostranstv. Nauka, Novosibirsk (in Russian).

Lamb, A.L., Leng, M.J., Sloane, H.J., Telford, R.J., 2005. A comparison of $\delta^{18} \mathrm{O}$ data from calcite and diatom silica from early Holocene in a small crater lake in the tropics. Palaeogeography, Palaeoclimatology, Palaeoecology 223, 290-302.

Lee, K.-S., Grundstein, A.J., Wenner, D.V., Choi, M.-S., Woo, N.-C., Lee, D.-H., 2003. Climatic controls on the stable isotopic composition of precipitation in Northeast Asia. Climate Research 23, 137-148.

Leng, M.J., Barker, P.A., 2006. A review of the oxygen isotope composition of lacustrine diatom silica for palaeoclimate reconstruction. Earth-Science Reviews 75, 5-27.

Leng, M.J., Marshall, J.D., 2004. Palaeoclimate interpretation of stable isotope data from lake sediment archives. Quaternary Science Reviews 23, 811-831.

Leng, M.J., Barker, P., Greenwood, P., Roberts, N., Reed, J.M., 2001. Oxygen isotope analysis of diatom silica and authigenic calcite from Lake Pinarbasi, Turkey. Journal of Paleolimnology 25, 343-349.

Lücke, A., Moschen, R., Schleser, G.H., 2005. High-temperature carbon reduction of silica: a novel approach for oxygen isotope analysis of biogenic opal. Geochemica et Cosmochimica Acta 69 (6), 1423-1433.

Lydolph, P.E., 1977. Climates of the Soviet Union. In: World Survey of Climatology, vol. 7. Elsevier Scientific Publishing Company, Amsterdam-Oxford-New York.

Mackay, A.W., Karabanov, E., Leng, M.J., Sloane, H.J., Morley, D.W., Panizzo, V.N., Khursevich, G., Williams, D., 2008. Reconstructing hydrological variability in Lake Baikal during MIS 11: an application of oxygen isotope analysis of diatom silica. Journal of Quaternary Science 23 (4), 365-374.

Mackay, A.W., Swann, G.E.A., Brewer, T.S., Leng, M.J., Morley, D.W., Piotrowska, N., Rioual, P., White, D., 2011. A reassessment of late glacial - Holocene diatom oxygen isotope record from Lake Baikal using a geochemical mass-balance approach. Journal of Quaternary Science 26 (6), 627-634.

Matheney, R.K., Knauth, L.P., 1989. Oxygen-isotope fractionation between marine biogenic silica and seawater. Geochimica et Cosmochimica Acta 53, 3207-3214.

Mayewski, P.A., Rohling, E.E., Stager, J.C., Karle, W., Maasch, K.A., Meeker, L.D., Meyerson, E.A., Gasse, F., van Kreveld, Sh, Holmgren, K., Lee-Thorp, J., Rosqvist, G., Rack, F., Staubwasser, M., Schneider, R.R., Steig, E.J., 2004. Holocene climate variability. Quaternary Research 62, 243-255.

Merlivat, L., Jouzel, J., 1979. Global climatic interpretation of the deuterium-oxygen 18 relationship for precipitation. Journal of Geophysical Research 84, 5029-5033.

Meyer, H., Schönicke, L., Wand, U., Hubberten, H.-W., Friedrichsen, H., 2000. Isotope studies of hydrogen and oxygen in ground ice - experiences with the equilibration technique. Isotopes in Environmental and Health Studies 36, 133-149.

Meyer, H., Dereviagin, A.Yu., Siegert, C., Hubberten, H.-W., Rachold, V., 2002. Paleoclimate studies on Bykovsky Peninsula, North Siberia; hydrogen and oxygen isotopes in ground ice. Polarforschung 70, 37-51.

Meyer, H., Schirrmeister, L., Yoshikawa, K., Opel, T., Wetterich, S., Hubberten, H.-W. Brown, J., 2010. Permafrost evidence for severe winter cooling during the Younger Dryas in northern Alaska. Geophysical Research Letters 37, L03501. doi:10.1029/2009GL041013.

Morley, D.W., Leng, M.J., Mackay, A.W., Sloane, H.J., Rioual, P., Batterbee, R.W., 2004 Cleaning of lake sediment samples for diatom oxygen isotope analysis. Journal of Palaeolimnology 31, 391-401. 
Morley, D.W., Leng, M.J., Mackay, A.W., Sloane, H.J., 2005. Late glacial and Holocene environmental change in the Lake Baikal region documented by oxygen isotopes from diatom silica. Global and Planetary Change 46, 221-233.

Moschen, R., Lücke, A., Schleser, G.H., 2005. Sensitivity of biogenic silica oxygen isotopes to changes in surface water temperature and palaeoclimatology. Geophysical Research Letters 32, L07708. doi:10.1029/2004GL022167.

Mügler, I., Gleixner, G., Günther, F., Mäusbacher, R., Daut, G., Schütt, B., Berking, J., Schwalb, A., Schwark, L., Xu, B., Yao, T., Zhu, L., Yi, C., 2010. A multi-proxy approach to reconstruct hydrological changes and Holocene climate development of Nam Co, Central Tibet. Journal of Paleolimnology 43, 625-648.

Nakagawa, T., Gotanda, K., Haraguchi, T., Danhara, T., Yonenobu, H., Brauer, A., Yokoyama, Y., Tada, R., Takemura, K., Staff, R.A., Payne, R., Bronk Ramsey, C., Bryant, C., Brock, F., Schlolaut, G., Marshall, M., Tarasov, P., Lamb, H., Suigetsu 2006 Project Members, 2012. SG06, a fully continuous and varved sediment core from Lake Suigetsu, Japan: stratigraphy and potential for improving the radiocarbon calibration model and understanding of late Quaternary climate changes. Quaternary Science Reviews 36, 164-176.

Numaguti, A., 1999. Origin and recycling processes of precipitating water over the Eurasian continent: experiments using an atmospheric general circulation model. Journal of Geophysical Research 104, 1957-1972.

Paul, C.A., Rühland, K.M., Smol, J.P., 2010. Diatom-inferred climatic and environmental changes over the last 9000 years from a low Arctic (Nunavut, Canada) tundra lake. Palaeogeography, Palaeoclimatology, Palaeoecology 291, 205-216.

Peng, T.-R., Wang, C.-H., Huang, C.-C., Fei, L.-Y., Chen, C.-T.A., Hwong, J.-L., 2010. Stable isotopic characteristic of Taiwan's precipitation: a case study of western Pacific monsoon region. Earth and Planetary Science Letters 289, 357-366.

Polonnykh, A.K., 1988. Phytoplankton ozer Irkana, Kotokel i ego produkciya. Sbornik Nauchnih Trudov GosNIOPH 279, 17-24 (in Russian).

Prokopenko, A.A., Khursevich, G.K., Bezrukova, E.V., Kuzmin, M.I., Boes, X. Williams, D.F., Fedenya, S.A., Kulagina, N.V., Letunova, P.P., Abzaeva, A.A., 2007. Paleoenvironmental proxy records from Lake Hovsgol, Mongolia, and a synthesis of Holocene climate change in Lake Baikal watershed. Quaternary Research 68, 2-17.

Rosqvist, G., Jonsson, C., Yam, R., Karlen, W., Shemesh, A., 2004. Diatom oxygen isotopes in pro-glacial lake sediments from northern Sweden: a 5000 year record of atmospheric circulation. Quaternary Science Reviews 23, 851-859.

Rozanski, K., Araguás-Araguás, L., Gonfiantini, R., 1993. Isotopic patterns in modern global precipitation. Geophysical Monograph 78. In: Climate Change in Continental Isotope Records. American Geophysical Union, pp. 1-36.

Ryves, D.V., Jewson, D.H. Sturm, M., Battarbee, R.W., Flower, R.J., Mackay, A.W. Granin, N.G., 2003. Quantitative and qualitative relationships between planktonic diatom communities and diatom assemblages in sedimenting material and surface sediments in Lake Baikal, Siberia. Limnology and Oceanography 48, 1643-1661.

Schmidt, M., Botz, R., Rickert, D., Bohrmann, G., Hall, S.R., Mann, S., 2001. Oxygen isotopes of marine diatoms and relations to opal-A maturation. Geochimica et Cosmochimica Acta 65, 201-211.

Seal, R.R., Shanks, W.C., 1998. Oxygen and hydrogen isotope systematics of Lake Baikal, Siberia: implications for paleoclimate studies. Limnology and Oceanography $43,1251-1261$.

Shemesh, A., Charles, C.D., Fairbanks, R.G., 1992. Oxygen isotopes in biogenic silica: global changes in ocean temperature and isotopic composition. Science 256, 1434-1436.

Shemesh, A., Burckle, L.H., Hays, J.D., 1995. Late Pleistocene oxygen isotope records of biogenic silica from the Atlantic sector of the Southern Ocean. Paleoceanography $10,179-196$.
Shemesh, A., Rosqvist, G., Rietti-Shati, M., Rubensdotter, L., Bigler, C., Yam, R., Karlen, W., 2001. Holocene climatic change in Swedish Lapland inferred from an oxygen-isotope record of lacustrine biogenic silica. The Holocene 11 (4) 447-454.

Shichi, K., Takahara, H., Krivonogov, S.K., Bezrukova, E.V., Kashiwaya, K., Takehara, A., Nakamura, T., 2009. Late Pleistocene and Holocene vegetation and climate records from Lake Kotokel, central Baikal region. Quaternary International 205 (1-2), 98-110.

Svensson, A., Andersen, K.K., Bigler, M., Clausen, H.B., Dahl-Jensen, D., Davies, S.M. Johnsen, S.J., Muscheler, R., Parrenin, F., Rasmussen, S.O., Röthlisberger, R, Seierstad, I., Steffensen, J.P., Vinther, B.M., 2008. A 60000 year Greenland stratigraphic ice core chronology. Climate of the Past 4, 47-57.

Swann, G.E.A., Leng, M.J., 2009. A review of diatom $\delta^{18} \mathrm{O}$ in palaeoceanography. Quaternary Science Reviews 28, 384-398.

Swann, G.E.A., Mackay, A.W., Leng, M.J., Demory, F., 2005. Climatic change in Central Asia during MIS 3/2: a case study using biological responses from Lake Baikal. Global and Planetary Change 46, 235-253.

Swann, G.E.A., Leng, M.J., Sloane, H.J., Maslin, M.A., 2008. Isotope offsets in marine diatom $\delta^{18} \mathrm{O}$ over the last $200 \mathrm{ka}$. Journal of Quaternary Science 23, 389-400.

Swann, G.E.A., Leng, M.J., Juschus, O., Melles, M., Brigham-Grette, J., Sloane, H.J. 2010. A combined oxygen and silicon diatom isotope record of Late Quaternary change in Lake El'gygytgyn, North East Siberia. Quaternary Science Reviews 29 774-786.

Tarasov, P.E., Bezrukova, E.V., Krivonogov, S.K., 2009. Late Glacial and Holocene changes in vegetation cover and climate in southern Siberia derived from a 15 kyr long pollen record from Lake Kotokel. Climate of the Past 5, 285-295.

Vipper, P.B., Smirnov, N.N., 1979. The Studying of Biogeocenozes History by the Fresh Water Lakes Bottom Deposits. Obshchie Metody Izucheniya Istorii Sovremennykh Ekosistem. Nauka, Moscow, pp. 14-39 (in Russian).

Walker, M., Johnsen, S., Rasmussen, S.O., Popp, T., Steffensen, J.-P., Gibbard, P., Hoek, W., Lowe, J., Andrews, J., Björck, S., Cwynar, L.C., Hughen, K., Kershaw, P., Kromer, B., Litt, T., Lowe, D.J., Nakagawa, T., Newnham, R., Schwander, J., 2009. Formal definition and dating of the GSSP (Global Stratotype Section and Point) for the base of the Holocene using the Greenland NGRIP ice core, and selected auxiliary records. Journal of Quaternary Science 24 (1), 3-17.

Wang, H., Liu, H., Zhu, J., Yin, Y., 2010. Holocene environmental changes as recorded by mineral magnetism of sediments from Anguli-nuur Lake, southeastern Inne Mongolia Plateau, China. Palaeogeography, Palaeoclimatology, Palaeoecology 285, 30-49.

Wang, L., Li, J., Lu, H., Gu, Z., Rioual, P., Hao, Q., Mackay, A.W., Jiang, W., Cai, B., Xu, B. Han, J., Chu, G., 2012. The East Asian winter monsoon over the last 15,500 years: its links to high-latitudes and tropical climate systems and complex correlation to the summer monsoon. Quaternary Science Reviews 32, 131-142.

Wanner, H., Beer, J., Bütikofer, J., Crowley, TJ., Cubasch, U., Flückiger, J., Goosse, H. Grosjean, M., Joos, F., Kaplan, J.O., Küttel, M., Müller, S.A., Prentice, I.C. Solomina, O., Stocker, T.F., Tarasov, P., Wagner, M., Widmann, M., 2008. Mid- to late Holocene climate change - an overview. Quaternary Science Reviews 27 (19-20), 1791-1828.

Watanabe, T., Nakamura, T., Watanabe, N.T., Kakegawa, T., Nishimura, M. Shimokawara, M., Matsunaka, T., Senda, R., Kawai, T., 2009. A new age model for the sediment cores from Academician ridge (Lake Baikal) based on high-timeresolution AMS $14 \mathrm{C}$ data sets over the last $30 \mathrm{kyr}$ : paleoclimatic and environmental implications. Earth and Planetary Science Letters 286, 347-354.

Yuan, D.X., Cheng, H., Edwards, R.L., Dykoski, C.A., Kelly, M.J., Zhang, M.L., Qing, J.M. Lin, Y.S., Wang, Y.J., Wu, J.Y., Dorale, J.A., An, Z.S., Cai, Y.J., 2004. Timing, duration, and transitions of the Last Interglacial Asian monsoon. Science 304, 575-578. 